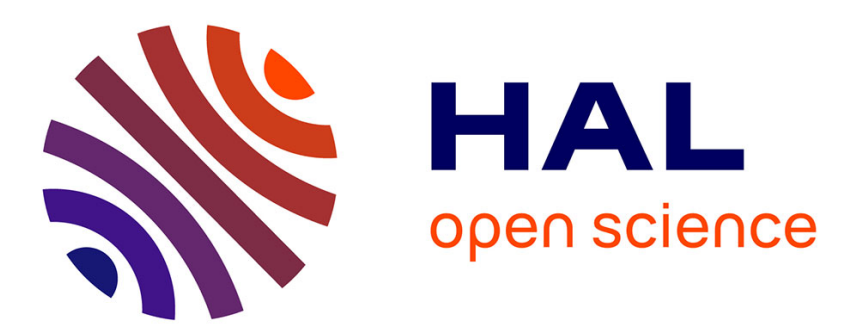

\title{
Dialkyl(butadiene)cyclopentadienylmolybdenum(III) Complexes. Synthesis, Characterization, and Reactivity
} Erwan Le Grognec, Rinaldo Poli, Philippe Richard

\section{To cite this version:}

Erwan Le Grognec, Rinaldo Poli, Philippe Richard. Dialkyl(butadiene)cyclopentadienylmolybdenum(III) Complexes. Synthesis, Characterization, and Reactivity. Organometallics, 2000, 19 (19), pp.3842-3853. 10.1021/om000329t . hal-03295929

\section{HAL Id: hal-03295929 \\ https://hal.science/hal-03295929}

Submitted on 28 Jul 2021

HAL is a multi-disciplinary open access archive for the deposit and dissemination of scientific research documents, whether they are published or not. The documents may come from teaching and research institutions in France or abroad, or from public or private research centers.
L'archive ouverte pluridisciplinaire HAL, est destinée au dépôt et à la diffusion de documents scientifiques de niveau recherche, publiés ou non, émanant des établissements d'enseignement et de recherche français ou étrangers, des laboratoires publics ou privés. 


\title{
Dialkyl(butadiene)cyclopentadienylmolybdenum(III) Complexes. Synthesis, Characterization, and Reactivity
}

Erwan Le Grognec, Rinaldo Poli,* and Philippe Richard

Laboratoire de Synthèse et d'Electrosynthèse Organométalliques, Université de Bourgogne, Faculté des Sciences "Gabriel", 6 Boulevard Gabriel, 21000 Dijon, France

Correspondence to: Prof. Rinaldo Poli

tel: $+33-03.80 .39 .68 .81$

fax: $+33-03.80 .39 .60 .98$

E-MAIL: Rinaldo.Poli@,u-bourgogne.fr

\begin{abstract}
Treatment of $\mathrm{CpMo}\left(\eta^{4}\right.$-diene) $\mathrm{Cl}_{2}$ (diene = 1,3-butadiene, $\mathrm{C}_{4} \mathrm{H}_{6}, \mathbf{1}$; isoprene, $\mathrm{C}_{5} \mathrm{H}_{8}, \mathbf{1}^{\prime} ; 2,3-$ dimethyl-1,3-butadiene, $\left.\mathrm{C}_{6} \mathrm{H}_{10}, \mathbf{1}^{\prime \prime}\right)$ in diethyl ether at low temperature with 2 equiv of alkylmagnesium $\mathrm{RMgX}$ reagents affords the corresponding dialkyl complexes $\mathrm{CpMo}\left(\eta^{4}-1,3-\right.$ diene)R2 (2, 2', 2", $\left.\mathrm{R}=\mathrm{CH}_{3}, \mathbf{a} ; \mathrm{CH}_{2} \mathrm{Ph}, \mathbf{b} ; \mathrm{CH}_{2} \mathrm{SiMe}_{3}, \mathbf{c}\right)$. These species are isolable in moderate yields and have been fully characterized by EPR, elemental analyses, and cyclic voltammetry. They all show a reversible reduction process at relatively low potentials and an irreversible oxidation. The structure of 2"a was confirmed by single-crystal X-ray diffraction. The mixed complex $\mathrm{CpMo}\left(\eta^{4}-\mathrm{C}_{4} \mathrm{H}_{6}\right) \mathrm{Cl}\left(\mathrm{CH}_{3}\right), \mathbf{3}$, has also been obtained by selective monomethylation of $\mathbf{1}$. A slow ligand redistribution process occurs between equivalent amounts of $\mathbf{1}$ and $\mathbf{2 a}$ to afford $\mathbf{3}$ quantitatively. Compound 3 slowly decomposes by elimination of a $\mathrm{CH}_{3}$ group, yielding
\end{abstract}


compound $\left[\mathrm{CpMo}\left(\eta^{4}-\mathrm{C}_{4} \mathrm{H}_{6}\right) \mathrm{Cl}\right]_{2}, \quad 4$, which has been structurally characterized by X-ray crystallography. Arylation with $\mathrm{PhMgBr}$ or $\left(\mathrm{C}_{6} \mathrm{H}_{2} \mathrm{Me}_{3}-2,4,6\right) \mathrm{MgBr}$ provides EPR evidence for formation of arylated Mo(III) products. However, the isolation and crystallographic characterization of $\left[\mathrm{CpMo}\left(\eta^{4}-\mathrm{C}_{4} \mathrm{H}_{4} \mathrm{Me}_{2}-2,3\right) \mathrm{Br}_{0.77} \mathrm{Cl}_{0.23}\right]_{2}, 4$ ", for the mesityl reaction indicates that halide exchange and electron transfer processes also take place competitively. Complex $2 \mathbf{a}$ does not react with Lewis bases such as phosphines or carbon monoxide nor with weak Brønsted acids $\left(\mathrm{MeOH}, \mathrm{H}_{2} \mathrm{O}, \mathrm{CH}_{3} \mathrm{COOH}, \mathrm{H}_{3} \mathrm{PO}_{4}, \mathrm{H}_{3} \mathrm{O}^{+}\right)$. Protonolysis of the Mo- $\mathrm{R}$ bond could only be observed by interaction with $\mathrm{HCl}, \mathrm{HBF}_{4}$, and $\mathrm{CF}_{3} \mathrm{COOD}$, with formation of $\mathrm{CH}_{4}$ or $\mathrm{CH}_{3} \mathrm{D}$. Compounds $\mathrm{CpMo}\left(\eta^{4}-\mathrm{C}_{6} \mathrm{H}_{10}\right)\left(\mathrm{CH}_{3}\right)\left(\mathrm{OCOCF}_{3}\right), \mathbf{5}$, and $\mathrm{CpMo}\left(\eta^{4}-\mathrm{C}_{6} \mathrm{H}_{10}\right)\left(\mathrm{OCOCF}_{3}\right)_{2}$, 6, have been isolated from the reaction between 2"a and 1 or 2 equiv of $\mathrm{CF}_{3} \mathrm{COOD}$, respectively. Compound 6 has been structurally characterized by X-ray crystallography.

\section{Introduction}

There has long been an interest in free radicals in organometallic chemistry, because the presence of unpaired electrons may open up new reactivity pathways that are unavailable to the related and more frequently studied diamagnetic analogues. ${ }^{1-5}$ In addition, fundamental reactions that are well established for diamagnetic compounds are often found to be accelerated upon transformation (e.g., by oxidation or reduction) to radical species. ${ }^{6}$ A particularly interesting class of radical compounds are those containing alkyl ligands, since these are involved in most industrially relevant catalytic processes. The conditions for the inertness of transition metal alkyl compounds toward decomposition processes (i.e., by $\alpha$ - or $\beta-\mathrm{H}$ elimination processes, reductive elimination, etc.) are usually stricter in radical species. A large variety of radical systems containing alkyl ligands has, however, been described. Selected examples by class are $\mathrm{Cp}_{2} \mathrm{MR}_{2}$ $(\mathrm{M}=\mathrm{Nb}, \mathrm{Ta}),{ }^{7-9}\left[\mathrm{Cp}_{2} \mathrm{WR}_{2}\right]^{+},{ }^{10-12}$ and $\mathrm{CpCr}(\mathrm{NO})(\mathrm{L}) \mathrm{R} \cdot{ }^{13,14}$

As part of a systematic study of 17-electron monocyclopentadienyl complexes of the general formula $\mathrm{CpMoL}_{2} \mathrm{X}_{2}$ as starting materials or reactive intermediates for organometallic chemistry and catalysis, we reported a few years ago ${ }^{15}$ the formation of a transient paramagnetic dimethylmolybdenum(III) complex, $\mathrm{CpMo}\left(\mathrm{CH}_{3}\right)_{2}\left(\mathrm{PMe}_{3}\right)_{2}$, by the low-temperature alkylation of the dichloride precursor. This product was characterized in situ by EPR spectroscopy but could not be isolated because decomposition takes place at temperatures greater than ca. $-20{ }^{\circ} \mathrm{C}$, with 
homolytic cleavage of one $\mathrm{Mo}-\mathrm{CH}_{3}$ bond. More recently, we have observed a similar instability for the methylation product of $\mathrm{CpMoCl}_{2}\left(\mathrm{MeSCH}_{2} \mathrm{CH}_{2} \mathrm{PPh}_{2}\right),{ }^{16}$ and similar difficulties were encountered by Fryzuk et al. in the alkylation of $\left[\eta^{5}: P, P^{\prime}-\mathrm{C}_{5} \mathrm{H}_{3}-1,3-\left(\mathrm{SiMe}_{2} \mathrm{CH} 2 \mathrm{P}^{\mathrm{i}} \mathrm{Pr}_{2}\right)_{2}\right] \mathrm{MoCl}_{2}{ }^{17}$ In parallel studies, we have found a novel high-yield synthesis of the previously known ${ }^{18}$ $\mathrm{CpMo}\left(\eta^{4}\right.$-butadiene $) \mathrm{Cl}_{2}$ and have started to investigate its reactivity. ${ }^{19} \mathrm{We}$ now report that the reaction of this compound and similar diene derivatives with several alkylating reagents affords the first isolable mononuclear alkyl complexes of Mo(III). Somewhat unexpectedly, we find these products to be chemically inert under a variety of conditions. A portion of this work has been previously communicated. ${ }^{20}$

\section{Results and Discussion}

1. Preparation of the Diene-Containing Dichloride Precursors. The butadiene and isoprene compounds $\mathbf{1}$ and $\mathbf{1}$ ' were first reported by Davidson et al. ${ }^{18}$ as the products of diene addition to a Mo(II) precursor, which limits the yield to $50 \%$ at best. The diene complex $\mathbf{1}$ has been more recently synthesized in $90 \%$ yields by addition of butadiene to $\mathrm{CpMoCl}_{2} \cdot{ }^{21} \mathrm{By}$ the same procedure, we have now obtained 1' and the previously unreported 2,3-dimethylbutadiene analogue, 1", in isolated yields greater than $70 \%$ (eq 1). No reaction takes place between $\mathrm{CpMoCl}_{2}$ and cycloocta-1,3-diene or cycloocta-1,5-diene under the same conditions. These results may be rationalized by the steric repulsion between the diene ligand and the $\mathrm{Cp}$ ring, because the diene ligand preferentially adopts the supine (or endo) conformation in this system. ${ }^{18}$ In this respect, it can be noted that Davidson and co-workers have also reported derivatives with 1,3-pentadiene but could not obtain analogues with 1,3-cyclohexadiene.18 Compound 1" shows spectroscopic and electrochemical properties analogous to those previously reported for $\mathbf{1}$ and 1'. The cyclic voltammogram of $\mathbf{1}$ " in THF shows a reversible reduction wave at $-1.24 \mathrm{~V}$ vs ferrocene (cf. -1.08 and $-1.20 \mathrm{~V}$ for $\mathbf{1}$ and $\mathbf{1}^{\prime}$ ) and an irreversible oxidation at $0.66 \mathrm{~V}$ (cf. $0.75 \mathrm{~V}$ for $\mathbf{1}^{\prime}$ ), while the EPR spectrum of $\mathbf{1}$ " in THF shows a broad singlet at room temperature at $g=$ 1.994. Upon cooling, a hyperfine splitting to the external diene $\mathrm{H}$ atoms becomes visible, but unlike compounds $\mathbf{1}$ and $\mathbf{1}$, , no distinction between the anti and syn protons could be made.

$$
\mathrm{CpMoCl}_{2}+\text { diene } \rightarrow \mathrm{CpMoCl}_{2}\left(\eta^{4} \text {-diene }\right)
$$


(diene = 1,3-butadiene, $\mathbf{1} ;$ isoprene, $\mathbf{1}$ '; 2,3-dimethyl-1,3-butadiene, $\mathbf{1}$ ')

2. Alkylations of $\mathbf{C p M o C l 2}\left(\boldsymbol{\eta}^{4}\right.$-diene). Treatment of 1, 1', or 1" with 2.2 equiv of alkyl Grignard reagents in a diethyl ether or THF suspension at $-78{ }^{\circ} \mathrm{C}$ leads to the formation of the corresponding dialkyl complexes (see Scheme 1), which have been isolated as air- and lightsensitive green solids. All these products, however, are stable at room temperature as solids and in solution under an inert atmosphere and in the dark. In addition, compound 2a has been tested for thermal stability in toluene and shows, remarkably, less than 50\% decomposition after $22 \mathrm{~h}$ heating at $70{ }^{\circ} \mathrm{C}$, as monitored by EPR spectroscopy. The thermal stability both as solids and in solution critically depends on the absence of the magnesium salt byproducts, which must therefore be thoroughly eliminated. All these products are extremely soluble in all common organic solvents. Any attempt to crystallize compounds 2a, 2'a, 2b, and 2'b from cold concentrated solutions failed; however, they have been recovered as analytically pure powders by evaporation to dryness. In addition, the formulation of 2"a was confirmed by a single-crystal Xray analysis (vide infra).
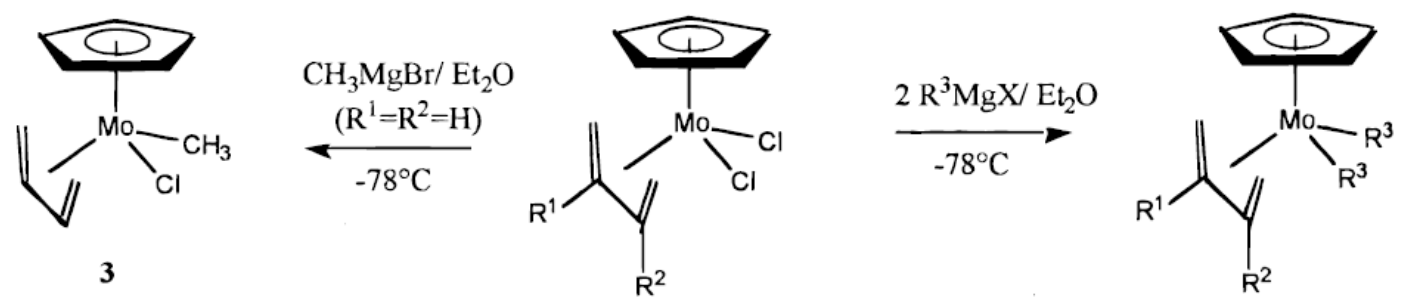

\begin{tabular}{cc|c}
$\mathrm{R}_{1}$ & $\mathrm{R}_{2}$ & \\
\hline $\mathrm{H}$ & $\mathrm{H}$ & $\mathbf{1}$ \\
$\mathrm{H}$ & $\mathrm{CH}_{3}$ & $1^{\prime}$ \\
$\mathrm{CH}_{3}$ & $\mathrm{CH}_{3}$ & $1^{\prime \prime}$
\end{tabular}

\begin{tabular}{lll|l}
$\mathrm{R}_{1}$ & $\mathrm{R}_{2}$ & $\mathrm{R}_{3}$ & \\
\hline $\mathrm{H}$ & $\mathrm{H}$ & $\mathrm{CH}_{3}$ & $\mathbf{2 a}$ \\
$\mathrm{H}$ & $\mathrm{H}$ & $\mathrm{CD}_{3}$ & $\mathbf{2 a - d} d^{6}$ \\
$\mathrm{H}$ & $\mathrm{H}$ & $\mathrm{CH}_{2} \mathrm{C}_{6} \mathrm{H}_{5}$ & $\mathbf{2 b}$ \\
$\mathrm{H}$ & $\mathrm{H}$ & $\mathrm{CH}_{2} \mathrm{Si}\left(\mathrm{CH}_{3}\right)_{3}$ & $\mathbf{2 c}$ \\
$\mathrm{H}$ & $\mathrm{CH}_{3}$ & $\mathrm{CH}_{3}$ & $\mathbf{2 ' a}$ \\
$\mathrm{CH}_{3}$ & $\mathrm{CH}_{3}$ & $\mathrm{CH}_{3}$ & $\mathbf{2} \mathbf{a}$ \\
$\mathrm{CH}_{3}$ & $\mathrm{CH}_{3}$ & $\mathrm{CH}_{2} \mathrm{C}_{6} \mathrm{H}_{5}$ & $\mathbf{2 " b}$ \\
$\mathrm{CH}_{3}$ & $\mathrm{CH}_{3}$ & $\mathrm{CH}_{2} \mathrm{Si}\left(\mathrm{CH}_{3}\right)_{3}$ & $\mathbf{2} \mathbf{c}$
\end{tabular}

Scheme 1

It is interesting to remark that the alkylation processes occur cleanly, with no competitive nucleophilic attack at the diene ligand nor SET processes. In comparison, the Mo(III) complex 
$\left[\mathrm{CpMo}\left(\eta^{4}-\mathrm{C}_{4} \mathrm{H}_{6}\right)\left(\eta^{3}-\mathrm{C}_{3} \mathrm{H}_{5}\right)\right]^{+}$undergoes competitive nucleophilic attack and one-electron reduction, ${ }^{22}$ while the $\mathrm{Mo}(\mathrm{II})$ complexes $\left[\mathrm{CpMo}\left(\eta^{4}-\mathrm{C}_{4} \mathrm{H}_{6}\right)_{2}\right]^{+}$and $\left[\mathrm{CpMo}\left(\eta^{4}-\text { diene }\right)(\mathrm{CO})_{2}\right]^{+}$ undergo facile addition of the carbanion at a diene terminal position. ${ }^{23-25}$ The arylation of 1 and 1" also provides evidence of competitive metathesis and SET processes (vide infra).

All dialkyl products exhibit a room-temperature EPR signal around $g=2.01$ with molybdenum satelites ( $a_{\mathrm{Mo}}$ ca. $33 \mathrm{G}$ ) due to ${ }^{95} \mathrm{Mo}(15.9 \%)$ and ${ }^{97} \mathrm{Mo}(9.5 \%)$, both having $I=5 / 2$. The spectra additionally show diagnostic hyperfine couplings to the diene terminal $\mathrm{H}$ atoms and to the alkyl R-H atoms. Like the previously described compounds $\mathbf{1}, \mathbf{1} \phi, 18$ and $\left[\mathrm{CpMo}\left(\eta^{4}-\right.\right.$ $\left.\left.\mathrm{C}_{4} \mathrm{H}_{6}\right)\left(\eta^{3}-\mathrm{C}_{3} \mathrm{H}_{5}\right)\right]^{+},{ }^{21}$ the $\mathrm{CpMo}(\mathrm{III})$ diene complexes reported here do not show hyperfine couplings to the diene internal $\mathrm{H}$ atoms nor to the $\mathrm{Cp} \mathrm{H}$ atoms in the EPR spectrum. The $\mathrm{H}$ couplings may be observed in some cases for dilute solutions at room temperature (2b, 2"'b, $\mathbf{2 c}$, 2"c), whereas in all the other cases they are evident only at low temperature. The spectra of complexes $\mathbf{2 a}$ and $\mathbf{2 a}-\boldsymbol{d}_{\mathbf{6}}$ are shown in the figure of the preliminary communication. ${ }^{20}$ Compounds with identical alkyl ligands and different substitution on the diene ligand show similar spectra (e.g., 2a, 2'a, and 2'a). Representative spectra for the bis(trimethylsilylmethyl) and dibenzyl derivatives are shown in Figure 1.

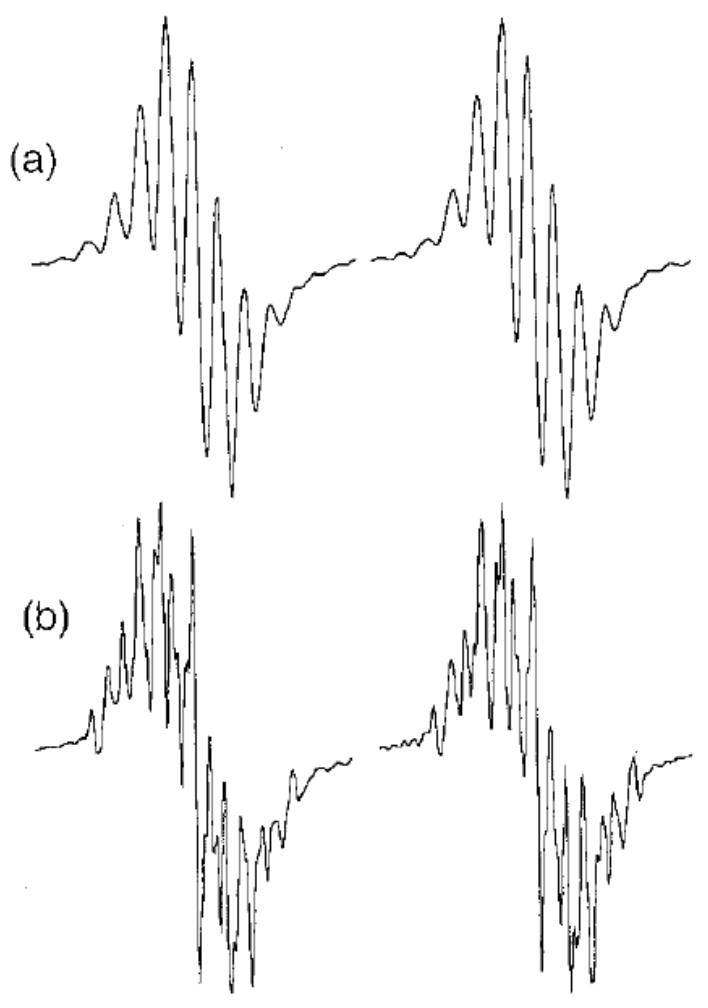


Figure 1. Experimental (left) and simulated (right) EPR spectra of compounds $\mathrm{CpMo}\left(\mathrm{R}^{3}\right)_{2}\left(\eta^{4}-\mathrm{CH}_{2}=\mathrm{CR}^{1}-\mathrm{CR}^{2}=\mathrm{CH}_{2}\right)$. (a) $2 \mathbf{b}$ in pentane at $-80{ }^{\circ} \mathrm{C}$; (b) $2 \mathbf{c}$ in pentane at $-80{ }^{\circ} \mathrm{C}$.

As previously discussed for compound $\mathbf{2 a},{ }^{20}$ the spectra of $\mathbf{2}$ 'a and $\mathbf{2}$ ''a qualitatively exhibit an apparent binomial undecet pattern, due to the unresolved coupling $\left(a_{\mathrm{H}} \mathrm{ca} .5 .5 \mathrm{G}\right)$ to $10 \mathrm{H}$ atoms of three different kinds: the six methyl hydrogens and the four (two syn and two anti) external diene hydrogens. In accord with this interpretation, the EPR resonance of the $\mathrm{CD}_{3}$ homologue $\mathbf{2 a}-\mathbf{d}_{\mathbf{6}}$ is reduced to a broad quintet with identical $g, a_{\mathrm{Mo}}$, and $a_{\mathrm{H}}$ values as $\mathbf{2 a}$ under similar conditions. The individual coupling constants reported in the Experimental Section derive from a standard simulation and fitting of the experimental spectra on the basis of the proposed spin system. The spectra of the $\mathrm{CH}_{2} \mathrm{Ph}$ derivatives (2b and $\mathbf{2}$ 'b) and $\mathrm{CH}_{2} \mathrm{SiMe}_{3}$ derivatives (2c and 2"c) analogously show couplings to the diene terminal $\mathrm{H}$ atoms and alkyl R-H atoms. In these cases, the spectra are more complex because the coupling constants to the different kinds of $\mathrm{H}$ atoms are sufficiently distinct (see Figure 1).

The structure of compound 2"a has been determined by a single-crystal X-ray analysis. Two independent, noninteracting, and essentially identical molecules are contained in the asymmetric unit. Selected bond distances and angles for both molecules are collected and compared in Table 1. A view of one of them is shown in Figure 2. The geometry parallels that reported by Davidson and co-workers for compound 1, ${ }^{18}$ including the supine conformation adopted by the diene ligand. The diene ligand has longer lateral $\mathrm{C}-\mathrm{C}$ bonds with respect to the internal one (averages are 1.426(4) and 1.394(4) $\AA$ over the two independent molecules), indicating significant back-bonding. These values are not too different than those found for $\mathbf{1}$ (1.410(6) and 1.364(5) $\AA$, respectively). ${ }^{18}$ The values of $d$ (average difference between Mo-Clateral

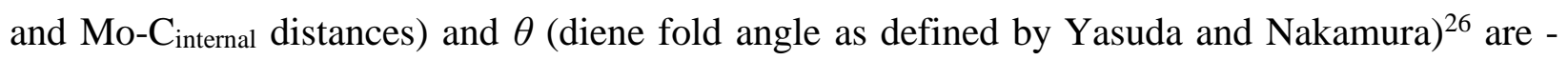
$0.135 \AA$ and $93.97^{\circ}$ for one molecule and $-0.129 \AA$ and $93.64^{\circ}$ for the other one. By comparison, the corresponding values for compound 1 are $-0.086 \AA$ and $93.33^{\circ}$. These values indicate that the electronic distribution in the Mo-diene bond is similar for compounds $\mathbf{1}$ and 2"a. Thus, the compounds can more appropriately be described as Mo(III)-diene complexes rather than as $\mathrm{Mo}(\mathrm{V})$ metallacyclopentene derivatives, although the contribution of the metallacyclopentene form is certainly not negligible. Most other crystallographically characterized Mo(III)-alkyl derivatives are based on the triply bonded $\mathrm{Mo}_{2} \mathrm{X}_{6}$ structural motif. ${ }^{27}$ The $\mathrm{Mo}^{-\mathrm{CH}_{3}}$ bond length in 
compound 2"a (average 2.224(9) $\AA$ over both molecules) is at the longer limit of the range previously established for these triply bonded molecules, as it might be expected from the greater electronic and coordinative saturation. Examples are shown in Table 2.

Table 1. Selected Bond Distances $(\AA)$ and Angles (deg) for Compound 2"a ${ }^{a}$

\begin{tabular}{|c|c|c|c|}
\hline Mo-CNT(1) & $2.019(5)$ & $\mathrm{Mo}^{*-\mathrm{CNT}}\left(1^{*}\right)$ & $2.021(4)$ \\
\hline Mo-CNT(2) & $1.925(3)$ & $\mathrm{Mo}^{*}$-CNT $(2 *)$ & $1.928(3)$ \\
\hline Mo-C(1) & $2.227(3)$ & $\mathrm{Mo}^{*-\mathrm{C}}(1 *)$ & $2.235(3)$ \\
\hline Mo-C(2) & $2.362(2)$ & $\mathrm{Mo}^{*}-\mathrm{C}(2 *)$ & $2.362(2)$ \\
\hline Mo-C(3) & $2.355(2)$ & $\mathrm{Mo}^{*}-\mathrm{C}\left(3^{*}\right)$ & $2.355(2)$ \\
\hline Mo-C(4) & $2.219(3)$ & $\mathrm{Mo}^{*}-\mathrm{C}(4 *)$ & $2.223(3)$ \\
\hline Mo-C(7) & $2.226(2)$ & $\mathrm{Mo}^{*}-\mathrm{C}(7 *)$ & $2.233(2)$ \\
\hline Mo-C(8) & $2.224(3)$ & $\mathrm{Mo}^{*}-\mathrm{C}(8 *)$ & $2.211(2)$ \\
\hline $\mathrm{C}(1)-\mathrm{C}(2)$ & $1.425(4)$ & $\mathrm{C}\left(1^{*}\right)-\mathrm{C}\left(2^{*}\right)$ & $1.428(3)$ \\
\hline$C(2)-C(3)$ & $1.397(4)$ & $\mathrm{C}\left(2^{*}\right)-\mathrm{C}\left(3^{*}\right)$ & $1.391(3)$ \\
\hline$C(3)-C(4)$ & $1.421(4)$ & $\mathrm{C}\left(3^{*}\right)-\mathrm{C}\left(4^{*}\right)$ & $1.431(4)$ \\
\hline CNT(1)-Mo-CNT(2) & $135.9(6)$ & $\mathrm{CNT}\left(1^{*}\right)-\mathrm{Mo}^{*}-\mathrm{CNT}\left(2^{*}\right)$ & $136.3(5)$ \\
\hline CNT(1)-Mo-C(7) & $112.5(4)$ & $\mathrm{CNT}\left(1^{*}\right)-\mathrm{Mo}^{*-\mathrm{C}}\left(7^{*}\right)$ & $111.3(3)$ \\
\hline CNT(1)-Mo-C(8) & $112.6(3)$ & $\mathrm{CNT}\left(1^{*}\right)-\mathrm{Mo}^{*-\mathrm{C}}\left(8^{*}\right)$ & $112.9(3)$ \\
\hline CNT(2)-Mo-C(7) & $100.9(2)$ & $\mathrm{CNT}\left(2^{*}\right)-\mathrm{Mo}^{*}-\mathrm{C}\left(7^{*}\right)$ & $101.3(2)$ \\
\hline CNT(2)-Mo-C(8) & 101.1(2) & $\mathrm{CNT}(2 *)-\mathrm{Mo}^{*}-\mathrm{C}\left(8^{*}\right)$ & $100.8(2)$ \\
\hline
\end{tabular}

${ }^{a} \mathrm{CNT}(1)$ is the center of gravity of the cyclopentadienyl ring [atoms $\left.\mathrm{C}(9)-\mathrm{C}(13)\right]$ ]. CNT(2) is the center of gravity of the butadiene ligand [atoms $\mathrm{C}(1)-\mathrm{C}(4)$ ]. Starred atoms refer to the second, independent molecule.

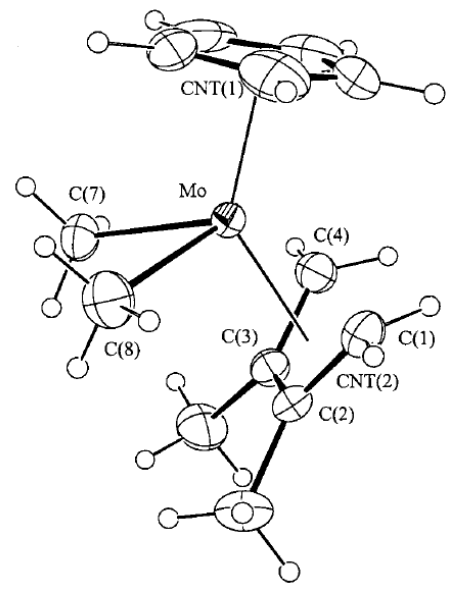

Figure 2. ORTEP89 view of compound 2"a with thermal ellipsoids drawn at the 30\% probability level.

Table 2. Selected Mo(III)-C Bond Distances

\begin{tabular}{lll}
\hline Compound & Mo-C distance $(\AA)$ & ref \\
\hline $\mathrm{Mo}_{2}\left(\mathrm{CH}_{2} \mathrm{SiMe}_{3}\right)_{6}$ & 2.131 & 28 \\
$\mathrm{Mo}_{2}\left(\mathrm{CH}_{2} \mathrm{Ph}\right)_{6}$ & $2.162(2)$ & 29 \\
$\mathrm{Mo}_{2} \mathrm{Me}_{2}(\mathrm{OtBu})_{4}(\mathrm{py})_{2}$ & $2.167(7)$ & 30 \\
$\mathrm{Mo}_{2}\left(\mathrm{CH}_{2} \mathrm{SiMe}_{3}\right)_{4}\left(\mathrm{O}^{+} \mathrm{Bu}\right)_{2}$ & $2.134(14)^{\mathrm{a}}$ & 31 \\
$\mathrm{Mo}_{2}\left(\mathrm{CH}_{2} \mathrm{SiMe}\right)_{4}\left(\mathrm{OC}_{6} \mathrm{H}_{3} \mathrm{Me}_{2}\right)_{2}$ & $2.090(7), 2.112(6)$ & 32 \\
$\mathrm{Mo}_{2}\left(\mathrm{CH}_{2} \mathrm{Ph}\right)_{2}\left(\mathrm{O}(\mathrm{Pr})_{4}\left(\mathrm{PMe}_{3}\right)\right.$ & $2.216(6)^{\mathrm{a}}$ & 33 \\
$\mathrm{Mo}_{2}\left(\mathrm{CH}_{2} \mathrm{Ph}\right)_{2}(\mathrm{O} \mathrm{Pr})_{4}(\mathrm{dmpm})$ & $2.206(10)$ & 33 \\
$\mathrm{Mo}_{2} \mathrm{Et}_{2}(\mathrm{NMe})_{4}$ & $2.164(7)^{\mathrm{a}}$ & 34 \\
$\mathrm{Mo}_{2}\left(\mathrm{CH}_{2} \mathrm{Ph}\right)_{2}\left(\mathrm{NMe}_{2}\right)_{4}$ & $2.19(1)^{\mathrm{a}}$ & 35,36
\end{tabular}




\begin{tabular}{lll}
$\mathrm{Mo}_{2}\left(\mathrm{CH}_{2} \mathrm{CH}_{2} \mathrm{CH}_{2} \mathrm{CH}_{2}\right)\left(\mathrm{NMe}_{2}\right)_{4}$ & $2.168(4)$ & 37 \\
$\mathrm{Mo}_{2} \mathrm{Et}_{2}\left(\mathrm{NMe}_{2}\right)_{2}\left(\mathrm{CH}_{3} \mathrm{C}_{6} \mathrm{H}_{4} \mathrm{~N}_{3} \mathrm{C}_{6} \mathrm{H}_{4} \mathrm{CH}_{3}\right)_{2}$ & $2.213(11)^{\mathrm{a}}$ & 38 \\
$\mathrm{Mo}_{2}\left(\mathrm{CH}_{2}{ }^{\mathrm{B}} \mathrm{Bu}\right)_{2}\left(\mathrm{O}_{2} \mathrm{CCH}_{3}\right)_{4}$ & $2.192(2)$ & 39 \\
$(\mathrm{iPrO})_{3} \mathrm{Mo} \equiv \mathrm{Mo}\left(\mathrm{CH}_{2} \mathrm{Ph}\right)_{2}\left(\mathrm{O}^{\mathrm{i} P r}\right)\left(\mathrm{PMe}_{3}\right)$ & $2.22(1)$ & 40 \\
\hline
\end{tabular}

${ }^{a}$ Average distance.

Since dialkylation reactions are known to occasionally afford byproducts of monoalkylation, especially with the bulkier alkylating agents, ${ }^{41}$ we deliberately synthesized and investigated the product of monomethylation for substrate 1, namely, compound 3; see Scheme 1. Treatment of 1 with only 1 equiv of $\mathrm{CH}_{3} \mathrm{MgBr}$ in a THF or toluene solution affords the expected monomethyl derivative $\mathbf{3}$ as an analytically and spectroscopically pure dark green powder. The EPR spectrum (shown in the figure of the preliminary communication) has the qualitative appearance of a binomial octet because of unresolved coupling to the butadiene syn and anti external $\mathrm{H}$ atoms. Both the $g$ value and the $a_{\mathrm{Mo}}$ and $a_{\mathrm{H}}$ coupling constants are similar for $2 \mathbf{a}$ and 3. This feature, therefore, does not allow us to rule out the presence of minor amounts of each compound as a contaminant in the other. The purity of both products, however, is unambiguously shown by the electrochemical studies; see next section. Other selective monoalkylation processes of dichloride precursors have been previously reported. ${ }^{42-44}$

\section{Cyclic Voltammetric Studies of the Alkylmolybdenum(III) Derivatives. All} alkylmolybdenum(III) derivatives have been investigated by cyclic voltammetry, since halfsandwich molybdenum(III) complexes usually display an interesting redox behavior. ${ }^{45}$ All compounds display a reversible reduction wave and an irreversible oxidation process. The latter one was investigated in greater details for $\mathbf{2 a}$, for which no return wave could be observed even at scan rates up to $1000 \mathrm{~V} \mathrm{~s}^{-1}$ or at low temperatures $\left(-30^{\circ} \mathrm{C}\right)$ in different solvents $(\mathrm{THF}, \mathrm{MeCN}$, or $\mathrm{CH}_{2} \mathrm{Cl}_{2}$ ). The important results are collected in Table 3. It is immediately apparent that the reduction potentials are much more negative for the dialkyl complexes than for the dihalide species. As could be predicted, the reversible reduction wave for the mixed complex $\mathbf{3}$ is located halfway between the potentials measured for the dichloro and dimethyl species $\mathbf{1}$ and $\mathbf{2 a}$. A similar situation was reported for compounds $\mathrm{Cp} * \mathrm{M}(\mathrm{NO}) \mathrm{XY}(\mathrm{M}=\mathrm{Mo}, \mathrm{W} ; \mathrm{X}, \mathrm{Y}=\mathrm{Cl}$, $\left.\mathrm{CH}_{2} \mathrm{CMe}_{3}\right){ }^{43}$ Therefore, cyclic voltammetry is the best method to evaluate the presence of monoalkylated species as a contaminant in the dialkylated products, and vice versa. The observed negative shift is approximately $0.5 \mathrm{~V}$ per $\mathrm{Cl} / \mathrm{R}$ substitution. Related systems where a process interconverting 18-electron and 17-electron species has been measured include $\left[\mathrm{Cp}_{2} \mathrm{WX}_{2}\right]^{n+}(n=$ 
$0,1)^{12}$ and $[\mathrm{CpCr}(\mathrm{NO})(\mathrm{L}) \mathrm{X}]^{n-}(n=0,1),{ }^{14,46}$ where the observed negative shifts per $\mathrm{Cl} / \mathrm{R}$ substitution are ca. $350 \mathrm{mV}(\mathrm{R}=\mathrm{Me})$ and $610 \mathrm{mV}\left(\mathrm{R}=\mathrm{CH}_{2} \mathrm{SiMe}_{3}\right)$, respectively. The irreversible oxidation process is also significantly shifted toward negative potentials on going from the dichloro to the dialkyl systems. Related systems where the conversion between 17- and 16-electron species has been observed, namely, $\left[\mathrm{Cp}_{2} \mathrm{MX}_{2}\right]^{n+}(n=0,1 ; \mathrm{M}=\mathrm{Ti}, \mathrm{Zr})^{47-49}$ and $\left[\left(\mathrm{C}_{5} \mathrm{R}_{5}\right) \mathrm{M}(\mathrm{NO}) \mathrm{X}_{2}\right]^{n-}(n=0,1 ; \mathrm{R}=\mathrm{H}, \mathrm{Me} ; \mathrm{M}=\mathrm{Mo}, \mathrm{W}),{ }^{43,50,51}$ show again similar negative shifts.

Table 3. Cyclic Voltammetric Data at Room Temperature in THF for All Compounds ${ }^{\mathrm{a}}$

\begin{tabular}{lll}
\hline Compound & $E_{1 / 2}\left(\mathrm{Mo}^{\mathrm{II}} / \mathrm{Mo}^{\mathrm{III}}\right)(\mathrm{V})$ & $E_{\mathrm{p}, \mathrm{a}}\left(\mathrm{Mo}^{\mathrm{III}} / \mathrm{Mo}^{\mathrm{IV}}\right)^{b}(\mathrm{~V})$ \\
\hline $\mathbf{1}^{c}$ & -1.11 & 0.73 \\
$\mathbf{1}$ & -1.19 & 0.75 \\
$\mathbf{1}$ & -1.24 & 0.66 \\
$\mathbf{2 a}$ & -2.09 & -0.17 \\
$\mathbf{2} \mathbf{a}$ & -2.13 & -0.18 \\
$\mathbf{2}$ 'a & -2.14 & -0.23 \\
$\mathbf{2 b}$ & -1.85 & -0.38 \\
$\mathbf{2}$ 'b & -1.85 & -0.34 \\
$\mathbf{2 c}$ & -2.01 & -0.26 \\
$\mathbf{2}$ 'c & -2.07 & -0.28 \\
$\mathbf{3}$ & -1.62 & $d$ \\
$\mathbf{5}$ & $-1.61^{e}$ & 0.27 \\
$\mathbf{6}$ & -1.00 & $d$ \\
\hline
\end{tabular}

${ }^{a}$ All potentials are relative to the ferrocene standard. ${ }^{b}$ Measured by using a scan rate of $200 \mathrm{mV} \mathrm{s}^{-1}$ for all compounds. ${ }^{c}$ This compound was also previously investigated by Davidson et al. ${ }^{18}$ (reversible reduction at $-1.09 \mathrm{~V}$ in THF and $-1.21 \mathrm{~V}$ in $\mathrm{CH}_{2} \mathrm{Cl}_{2}$; irreversible oxidation at $E_{\mathrm{p}, \mathrm{a}}=+0.62 \mathrm{~V}$ in $\left.\mathrm{CH}_{2} \mathrm{Cl}_{2}\right)$. ${ }^{d}$ An oxidation wave for this compound was not observed up to the discharge of the solvent $($ ca. $1.5 \mathrm{~V}) .{ }^{e}\left(i_{\mathrm{a}} / i_{\mathrm{c}}\right)<1$ (see text).

A comparison between members of homologous series shows that greater substitution on the diene ligand results in a small negative shift on both processes. For compounds with the same diene and different alkyl groups, the reduction potentials become less negative in the order $\mathrm{CH}_{3}<$ $\mathrm{CH}_{2} \mathrm{SiMe}_{3}<\mathrm{CH}_{2} \mathrm{Ph}$, in agreement with trends of the R-substituent electron-withdrawing properties $\left(\mathrm{H}<\mathrm{SiMe}_{3}<\mathrm{Ph}\right)$. On the other hand, the oxidation peak potential shifts in the opposite direction, in contrast with the above effect. However, since these oxidation processes are irreversible, the different observed potentials must also depend on the relative rates of the follow-up chemical processes.

4. Conproportionation Reaction of 1 and 2a. The selective formation of the monoalkylated complex 3 by methylation of 1 with 1 equiv of $\mathrm{CH}_{3} \mathrm{MgBr}$ could be rationalized in two possible ways. The first alkylation could proceed much more rapidly than the second one, and/or compound $\mathbf{3}$ could be thermodynamically favored relative to a 50:50 mixture of $\mathbf{1}$ and $\mathbf{2 a}$. 
Note that the greater solubility in THF of the monoalkylation product $\mathbf{3}$ with respect to the precursor $\mathbf{1}$ is a factor in favor of a competitive second alkylation. The rationalization based on thermodynamics was easily tested by monitoring a solution obtained by mixing equivalent amounts of the dichloro and dimethyl complexes; see eq 2.

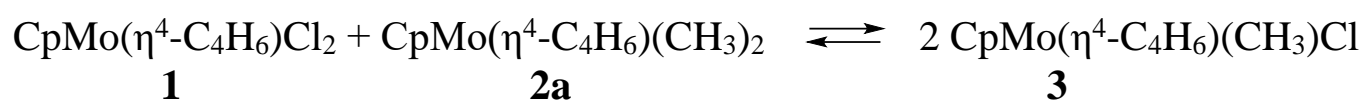

As discussed above, the EPR signal of $\mathbf{3}$ has a $\mathrm{g}$ value identical with that of $\mathbf{2 a}$. Thus, the EPR monitoring showed only the decrease of compound $\mathbf{1}$ and the increase of a signal corresponding to the sum of $\mathbf{2 a}$ and $\mathbf{3}$. On the other hand, cyclic voltammetry permitted us to follow the evolution of all three compounds independently; see Figure 3. It can be noted that the reaction is extremely slow and quantitative, a complete conversion requiring several weeks at room temperature. The slow rate of this ligand redistribution process also indicates that the thermodynamic preference of $\mathbf{3}$ relative to a mixture of $\mathbf{1}$ and $\mathbf{2 a}$ is not a sufficient criterion to rationalize the selectivity of the monoalkylation process. A much slower second alkylation step relative to the first one must also be invoked.

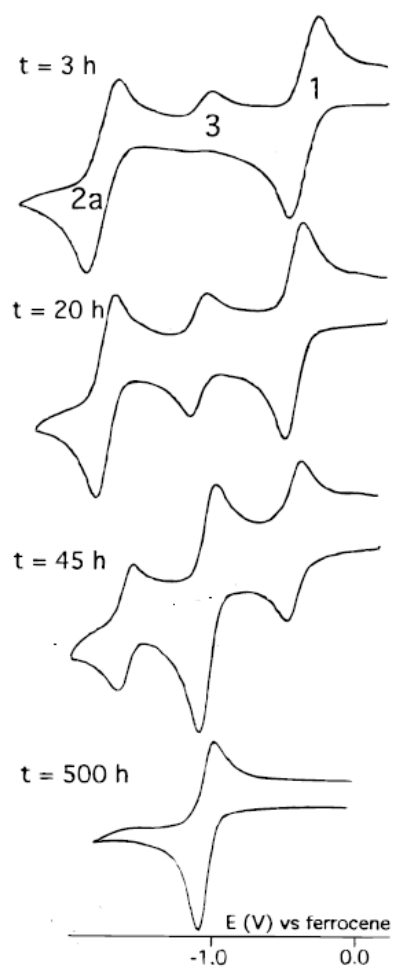


Figure 3. Cyclic voltammograms at different times of a THF solution obtained by mixing equimolar amounts of compounds $\mathbf{1}$ and $\mathbf{2 a}$.

Reaction 2 is an example of the general ligand redistribution process schematically described in eq 3, for which many examples are known. ${ }^{52-54}$ Of particular relevance here, because the metal and electronic configuration are the same, is the equilibrium between $\mathrm{CpMo}\left(\mathrm{PMe}_{3}\right)_{2} \mathrm{Cl}_{2}$ and $\mathrm{CpMo}\left(\mathrm{PMe}_{3}\right)_{2} \mathrm{I}_{2}$ on one side with the mixed system $\mathrm{CpMo}\left(\mathrm{PMe}_{3}\right)_{2}(\mathrm{Cl})(\mathrm{I})$ on the other side. ${ }^{54}$ This equilibrium was found to lie in slight favor of the mixed chloroiodo system with respect to the statistical distribution $\left(K=12-15\right.$ in $\mathrm{CH}_{2} \mathrm{Cl}_{2}$ and 20-28 in THF in the temperature range 22$35{ }^{\circ} \mathrm{C}$, corresponding to the experimental $H^{\circ}$ values of -0.7 and $-1.0 \mathrm{kcal} / \mathrm{mol}$, respectively). ${ }^{54}$ The essential completeness of reaction 2 means that this must be characterized by an even greater exothermicity. For a reaction of this kind, it can be safely assumed that the entropic and (PV) contributions are negligible, thus $G \sim H \sim E$. Total energy calculations for geometry optimized $\mathbf{1}$, 2a, and 3 by DFT/B3LYP methods afford an $E$ value of $-7.4 \mathrm{kcal} / \mathrm{mol}$ for the isodesmic reaction 2. From this value and the above assumptions, the equilibrium constant for reaction 2 is estimated as $K=2.7 \times 10^{5}$, in agreement with the observed complete conversion. A similar redistribution process, also thermodynamically favoring the mixed chloroalkyl species, is that involving $\mathrm{Cp}^{*}{ }_{2} \mathrm{MR}_{2}$ and $\mathrm{Cp}_{2}{ }_{2} \mathrm{MCl}_{2}\left(\mathrm{M}=\mathrm{Th}, \mathrm{U} ; \mathrm{R}=\mathrm{Me}, \mathrm{CH}_{2} \mathrm{SiMe}_{3}\right) .{ }^{42}$

$\mathrm{X}-\mathrm{M}-\mathrm{X}+\mathrm{Y}-\mathrm{M}-\mathrm{Y} \rightleftarrows 2 \mathrm{X}-\mathrm{M}-\mathrm{Y}$

The ligand redistribution process of eq 2 is much slower than the $\mathrm{Cl} / \mathrm{I}$ redistribution process mentioned above, for which the equilibrium position was attained within $48 \mathrm{~h}$ at room temperature. A possible reason for this slower rate is the reduced ability of the methyl groups to bridge two metals in a likely dinuclear intermediate.

5. Decomposition of 3 and Arylations of $\mathrm{CpMoCl}_{2}\left(\eta^{4}\right.$-diene). The di- $\mu$ chlorodimolybdenum(II) complex $\mathbf{4}$ crystallizes from a pentane solution of $\mathbf{3}$ upon prolonged standing in laboratory roomlight at room temperature. We believe that this conversion involves the expulsion of methyl radicals (eq 4), by analogy with the analogous process previously reported for $\mathrm{CpMo}\left(\mathrm{PMe}_{3}\right)_{2}\left(\mathrm{CH}_{3}\right)_{2 .}{ }^{15}$

$2 \mathrm{CpMo}\left(\eta^{4}-\mathrm{C}_{4} \mathrm{H}_{6}\right)\left(\mathrm{CH}_{3}\right) \mathrm{Cl} \rightarrow\left[\mathrm{CpMo}\left(\eta^{4}-\mathrm{C}_{4} \mathrm{H}_{6}\right)(\mu-\mathrm{Cl})\right]_{2}+2 \mathrm{CH}_{3} \cdot$ 
The structure of compound $\mathbf{4}$ is shown in Figure 4, and selected bond distances and angles are collected in Table 4. The basic geometry of the molecule is identical with that previously established for the isomorphous $\left[\mathrm{CpMo}\left(\eta^{4}-\mathrm{C}_{4} \mathrm{H}_{6}\right)(\mu-\mathrm{X})\right]_{2}$, $\mathrm{X}$ being a compositional disorder of $\mathrm{Br}$ (89\%) and $\mathrm{Cl}(11 \%) .21$ The metals are separated by the nonbonding distance of $3.96 \AA$ (cf. 4.08 $\AA$ for the $\mathrm{Br}_{0.89} \mathrm{Cl}_{0.11}$ analogue). The Mo-Cl distances are much shorter than the Mo-X distances in the above-mentioned $X$ analogue (2.6613(6) and 2.6570(6) $\AA$ ), in agreement with the different nature of the bridging halide atom. The reasonable thermal ellipsoid of the bridging $\mathrm{Cl}$ atom suggests that no significant compositional disorder (e.g., with Br) is present in this case. All other structural parameters are rather similar to the compositionally disordered $\mathrm{Br} 0.89 \mathrm{Cl0.11}$ analogue, including the previously defined ${ }^{26} \Delta d$ and $\theta$ values, these being $-0.075 \AA$ and $91.77^{\circ}$ for compound 4. These values are also similar to those reported above for compound 2"a, indicating that both compounds adopt a similar Mo-diene bonding situation.

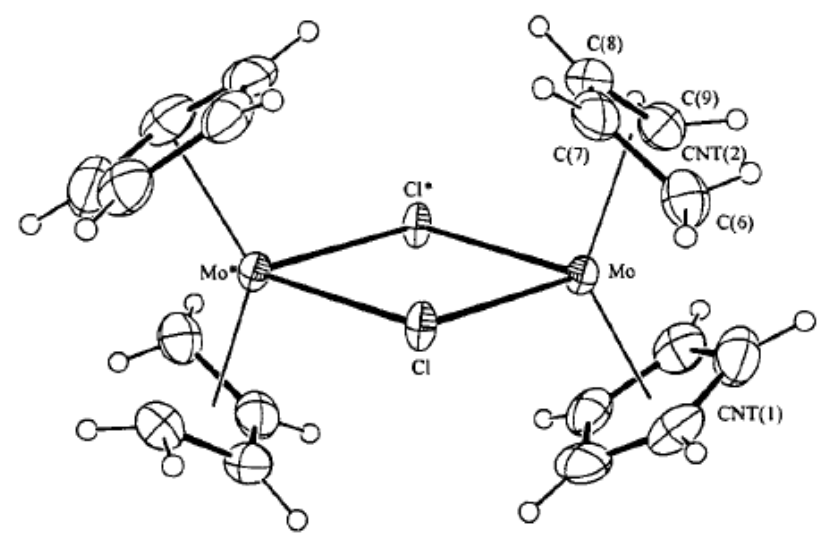

Figure 4. ORTEP ${ }^{89}$ view of compound 4 with thermal ellipsoids drawn at the $30 \%$ probability level.

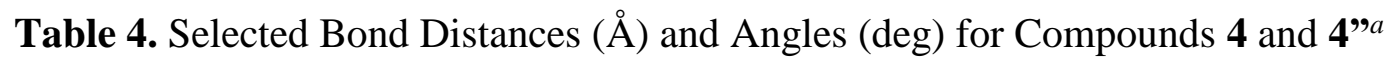

\begin{tabular}{|c|c|c|c|}
\hline \multirow[t]{2}{*}{ Mo-CNT(1) } & $1.922(6)$ & $\mathrm{Mo}(1)-\mathrm{CNT}(1)$ & $1.945(3)$ \\
\hline & & $\operatorname{Mo}(2)-\mathrm{CNT}(3)$ & $1.930(3)$ \\
\hline \multirow[t]{2}{*}{ Mo-CNT(2) } & $1.911(10)$ & Mo(1)-CNT(2) & $1.949(2)$ \\
\hline & & Mo(2)-CNT(4) & $1.946(2)$ \\
\hline $\mathrm{Mo}-\mathrm{Cl}$ & $2.5712(12)$ & $\mathrm{Mo}(1)-\mathrm{Br}$ & $2.6677(15)$ \\
\hline \multirow{3}{*}{ Mo-Cl\# } & $2.5766(12)$ & $\mathrm{Mo}(2)-\mathrm{Br}$ & $2.6667(15)$ \\
\hline & & $\mathrm{Mo}(1)-\mathrm{Cl}$ & $2.572(13)$ \\
\hline & & $\mathrm{Mo}(2)-\mathrm{Cl}$ & $2.607(13)$ \\
\hline Мo-C(6) & $2.246(6)$ & $\operatorname{Mo}(1)-C(7)$ & $2.4144(16)$ \\
\hline Mo-C(7) & $2.308(7)$ & $\operatorname{Mo}(1)-C(8)$ & $2.2206(19)$ \\
\hline Mo-C (8) & $2.330(7)$ & $\mathrm{Mo}(2)-\mathrm{C}(10)$ & $2.4105(16)$ \\
\hline Mo-C(9) & $2.242(7)$ & $\operatorname{Mo}(2)-\mathrm{C}(11)$ & $2.2206(18)$ \\
\hline$C(6)-C(7)$ & $1.434(11)$ & $C(7)-C(7) \#$ & $1.402(4)$ \\
\hline $\mathrm{C}(7)-\mathrm{C}(8)$ & $1.367(11)$ & $\mathrm{C}(7)-\mathrm{C}(8)$ & $1.440(3)$ \\
\hline \multirow[t]{2}{*}{$C(8)-C(9)$} & $1.428(11)$ & $\mathrm{C}(10)-\mathrm{C}(10) \#$ & $1.403(4)$ \\
\hline & & $\mathrm{C}(10)-\mathrm{C}(11)$ & $1.447(2)$ \\
\hline
\end{tabular}




\begin{tabular}{llll} 
CNT(1)-Mo-CNT(2) & $134.0(12)$ & CNT(1)-Mo(1)-CNT(2) & $132.2(3)$ \\
& & CNT(3)-Mo(2)-CNT(4) & $131.6(3)$ \\
CNT(1)-Mo-Cl & $112.6(3)$ & CNT(1)-Mo(1)-Br & $112.1(2)$ \\
CNT(1)-Mo-Cl\# & $111.9(4)$ & CNT(1)-Mo(1)-Cl & $113.4(9)$ \\
CNT(2)-Mo-Cl & $102.9(5)$ & CNT(2)-Mo(1)-Br & $104.5(1)$ \\
CNT(2)-Mo-Cl\# & $102.2(5)$ & CNT(2)-Mo(1)-Cl & $104.2(7)$ \\
& & CNT(3)-Mo(2)-Br & $113.3(2)$ \\
& & CNT(3)-Mo(2)-Cl & $113.4(9)$ \\
& & CNT(4)-Mo(2)-Br & $103.8(1)$ \\
& & CNT(4)-Mo(2)-Cl & $105.0(8)$ \\
Mo-Cl-Mo\# & $100.45(5)$ & Mo(1)-Br-Mo(2) & $101.95(4)$ \\
& & Mo(1)-Cl-Mo(2) & $106.3(4)$ \\
Cl-Mo-Cl\# & $79.55(7)$ & Br-Mo(1)-Br\# & $78.02(7)$ \\
& & Br-Mo(2)-Br\# & $78.05(7)$ \\
& & Cl-Mo(1)-Cl\# & $74.3(6)$ \\
& & Cl-Mo(2)-Cl\# & $73.1(5)$ \\
\hline
\end{tabular}

${ }^{a} \mathrm{CNT}(n)$ is the center of gravity of the cyclopentadienyl ring [for $4: n=1$, atoms $\mathrm{C}(1)-\mathrm{C}(5)$; for 4 ": $n=1$, atoms $\mathrm{C}(1), \mathrm{C}(2), \mathrm{C}(3), \mathrm{C}(3) \#, \mathrm{C}(2) \# ; n=3$, atoms $\mathrm{C}(4), \mathrm{C}(5), \mathrm{C}(6), \mathrm{C}(6) \#, \mathrm{C}(5) \#]$ or the butadiene ligand [for 4: $n=2$, atoms $\mathrm{C}(6)-\mathrm{C}(9)$; for $4 ": n=2$, atoms $\mathrm{C}(7), \mathrm{C}(7) \#, \mathrm{C}(8), \mathrm{C}(8) \# ; n=4$, atoms $\mathrm{C}(10), \mathrm{C}(10) \#, \mathrm{C}(11), \mathrm{C}(11) \#]$.

The isolation of the reduced product $\mathbf{4}$ from a solution originating from the monoalkylation of the dichloride complex 1 might lead to the proposal of an alternative formation mechanism, namely, direct reduction of $\mathbf{1}$ by the methyl Grignard reagent (a well-known phenomenon). Indeed, compound $\mathbf{1}$ was reported to undergo a reductive process by interaction with allylmagnesium bromide. ${ }^{21}$ However, the product of this reduction was found to be the abovementioned $\left[\mathrm{CpMo}\left(\eta^{4}-\mathrm{C}_{4} \mathrm{H}_{6}\right)(\mu-\mathrm{Br})_{0.89}(\mu-\mathrm{Cl})_{0.11}\right]_{2}$ rather than the pure chloro species. The reason for this result was traced to the relative preference of the two acidic centers $\mathrm{Mo}$ (II) and $\mathrm{Mg}$ (II) for the Lewis bases chloride and bromide, according to the HSAB theory. Thus, the 16-electron product of reduction, $\mathrm{CpMo}\left(\eta^{4}-\mathrm{C}_{4} \mathrm{H}_{6}\right) \mathrm{Cl}$, and $\mathrm{MgClBr}$ would exchange halides to afford $\mathrm{CpMo}\left(\eta^{4}-\mathrm{C}_{4} \mathrm{H}_{6}\right) \mathrm{Br}$ and $\mathrm{MgCl}_{2}$ in an equilibrium process. Now, the Grignard reagent employed to synthesize compound 3 was $\mathrm{CH}_{3} \mathrm{MgBr}$, while the $\mathrm{X}$-ray analysis indicates that compound $\mathbf{4}$ is a pure dichloro species. This means that compound $\mathbf{4}$ must necessarily form only after removal of the magnesium salts from the reaction mixture.

A competition between metathesis and reduction is observed in arylation reactions of compounds $\mathbf{1}$ and 1". The reactions between compounds $\mathbf{1}$ or $\mathbf{1}$ " with PhLi, PhMgI, or $\left(\mathrm{C}_{6} \mathrm{H}_{2} \mathrm{Me}_{3}-2,4,6\right) \mathrm{MgBr}$ lead to the formation of solutions containing new EPR active Mo(III) derivatives. These compounds, however, proved to be too unstable to isolate as pure products. The EPR spectra of these derivatives show as expected only an unresolved binomial quintet pattern because of coupling with the four terminal diene $\mathrm{H}$ atoms, since these derivatives lack any $\mathrm{R}-\mathrm{H}$ atom on the $\mathrm{R}^{3}$ substituent. The lack of any signature in the EPR spectrum by the aryl 
substituents does not unequivocally establish whether the observed products are diaryl or mixed chloro-aryl species. From the mesityl Grignard reaction, however, crystals of compound $\left[\mathrm{CpMo}\left(\eta^{4}-\mathrm{C}_{4} \mathrm{H}_{4} \mathrm{Me}_{2}-2,3\right)(\mu-\mathrm{Br})_{0.77}(\mu-\mathrm{Cl})_{0.23}\right]_{2}$, 4", were recovered, documenting that a reduction process takes place in this case as previously observed for the allyl Grignard reaction.21 The structure of 4", shown in Figure 5, is very similar to that of $\mathbf{4}$ and to that previously reported for compound $\left[\mathrm{CpMo}\left(\eta^{4}-\mathrm{C}_{4} \mathrm{H}_{6}\right)(\mu-\mathrm{Br})_{0.89}(\mu-\mathrm{Cl})_{0.11}\right]_{2}$ (see relevant parameters in Table 4). One minor difference, however, concerns the intimate geometry of the $\operatorname{Mo}\left(\eta^{4}\right.$-diene $)$ moiety. A greater tilting of the diene function is observed for 4", leading to longer Mo-C bonds for the internal C atoms and shorter ones for the external $\mathrm{C}$ atoms. This effect may be attributable to a steric repulsion between the methyl substituents at the diene 2 and 3 positions on one Mo atom with the $\mathrm{Cp}$ ligand on the adjacent Mo atom, rather than to a modification in the electronic structure of the Mo-diene bond (i.e., degree of back-bonding). In fact, the $\mathrm{C}-\mathrm{C}$ bond alternation is similar in the two compounds.

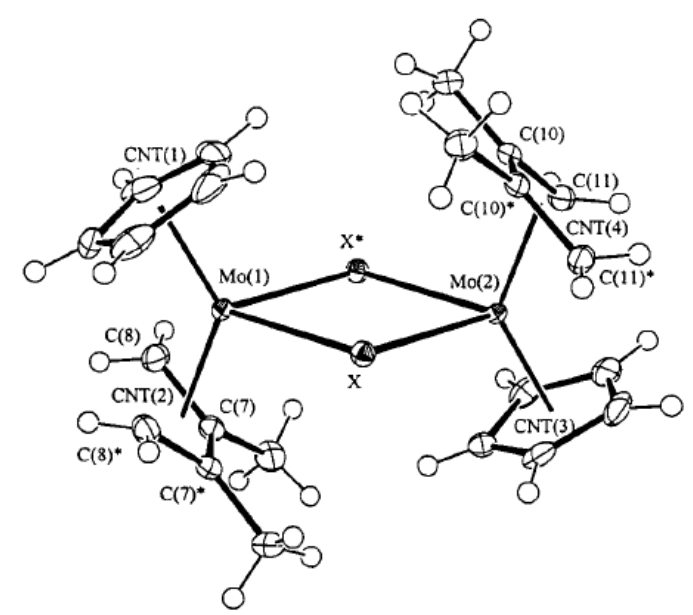

Figure 5. ORTEP ${ }^{89}$ view of compound 4" with thermal ellipsoids drawn at the $30 \%$ probability level. The bridging atom $\mathrm{X}$ is a compositional disorder of $\mathrm{Br}(77 \%)$ and $\mathrm{Cl}(23 \%)$. Only the major species $(\mathrm{X}=\mathrm{Br})$ is shown for clarity.

6. Chemical Reactivity Studies. 6.1. Inertness toward Lewis Bases. As stated above, the dialkyl derivatives $\mathbf{2}$ are thermally stable in the solid state and in solution, provided they are kept under an inert atmosphere and in the dark. They could be kept unaltered for several months when stored in flame-sealed and aluminum foil-wrapped ampules under argon at $4{ }^{\circ} \mathrm{C}$. The exposure of pentane solutions of $\mathbf{2 a}$ to the laboratory light induced a relative rapid decomposition, with the formation of a black precipitate, which does not dissolve in any common organic solvents. It is possible that a light-induced methyl radical elimination takes place as previously shown for the 
related $\mathrm{CpMo}\left(\mathrm{PMe}_{3}\right)_{2}\left(\mathrm{CH}_{3}\right)_{2}$ species and as suggested above for compound 3. If this is the case, the hypothetical $\mathrm{CpMo}\left(\eta^{4}-\mathrm{C}_{4} \mathrm{H}_{6}\right)\left(\mathrm{CH}_{3}\right)$ product would continue to decompose because, contrary to $\mathrm{CpMo}\left(\eta^{4}-\mathrm{C}_{4} \mathrm{H}_{6}\right) \mathrm{Cl}$, it is not able to stabilize itself by dimerization. No diamagnetic product of type $\mathrm{CpMo}\left(\eta^{4}-\mathrm{C}_{4} \mathrm{H}_{6}\right)\left(\mathrm{CH}_{3}\right)(\mathrm{L})$ could be identified by NMR $\left(\mathrm{L}=\mathrm{PMe}_{3}, \mathrm{PEt}_{3}\right)$ or IR $(\mathrm{L}=\mathrm{CO})$ spectroscopy when the photodecomposition was carried out in the presence of ligand L. As a matter of fact, the photodecomposition of $\mathbf{2 a}$ was retarded by the presence of L. For instance, the half-life of $\mathbf{2 a}$ was $28 \mathrm{~h}$ in the presence of a 3-fold excess of $\mathrm{PMe}_{3}$ at room temperature, as compared with $10 \mathrm{~h}$ in the absence of the phosphine. The only tentative rationalization that we are able to offer is that the additional ligand somehow acts as a quencher of the photodecomposition process.

No increased loss of starting material (with respect to control experiments carried out without the Lewis basic reagent and in the absence of light) occurs upon interaction of $2 \mathbf{a}$ with $\mathrm{PEt}_{3}$ at the reflux temperature of THF or with $\mathrm{CO}$ at $65{ }^{\circ} \mathrm{C}$ and $600 \mathrm{psi}$. This behavior is quite surprising because 17-electron organometallic species are believed to establish rapid (electronically favored, sterically disfavored) equilibria with formally 19-electron products of ligand addition, ${ }^{3,55,56}$ and because both alkyl-alkyl reductive elimination processes ${ }^{57-61}$ and the insertion of $\mathrm{CO}$ into $\mathrm{M}-\mathrm{R}$ bonds ${ }^{58,62-71}$ are known to be favored by an increase in metal oxidation state. Since half-sandwich derivatives of $\mathrm{Mo}(\mathrm{II})$ have been shown to undergo $\mathrm{CO}$ insertion processes, ${ }^{72,73}$ we were naturally expecting to observe a reaction between $\mathrm{CO}$ and the formally Mo(III) dialkyl derivatives reported here. However, despite the oxidation state, the metal has a high electron density, as demonstrated by the electrochemical studies described above, which probably renders ligand coordination and insertion/elimination processes thermodynamically and/or kinetically less favorable. A paramagnetic alkyl complex undergoing a CO insertion process is the 15-electron $\mathrm{Ti}(\mathrm{III})$ system $\left(\eta^{5}-\mathrm{C}_{5} \mathrm{R}^{\prime}{ }_{5}\right)_{2} \mathrm{Ti}-\mathrm{R}\left(\mathrm{R}^{\prime}=\mathrm{H}, \mathrm{Me}\right){ }^{74-76}$ The 17-electron complex $\mathrm{CpCr}(\mathrm{NO})\left(\mathrm{PPh}_{3}\right)\left(\mathrm{CH}_{2} \mathrm{SiMe}_{3}\right)$ is equally unreactive toward $\mathrm{CO}$, whereas the less sterically hindered $\mathrm{CpCr}(\mathrm{NO})($ pip $)\left(\mathrm{CH}_{2} \mathrm{Ph}\right)$ does react, but an insertion process does not occur. ${ }^{14}$ In light of the latter observation, steric hindrance toward the ligand addition process to $2 \mathbf{a}$ may also be an important factor.

6.2. Inertness toward Brønsted Acids. Reactivity studies of $2 \mathrm{a}$ with Brønsted acids also reveal the inertness of the $\mathrm{Mo}-\mathrm{CH}_{3}$ bond toward heterolytic cleavage. EPR monitoring reveals that no reaction takes place with the following acids, in order of increased strength (all in THF 
solution): $\mathrm{MeOH}, \mathrm{H}_{2} \mathrm{O}, \mathrm{CH}_{3} \mathrm{COOH}, \mathrm{H}_{3} \mathrm{PO}_{4}$, and $\mathrm{H}_{3} \mathrm{O}^{+}$(from aqueous $\mathrm{HCl}$ ). On the other hand, gaseous $\mathrm{HCl}$ in toluene converts $\mathbf{2 a}$ to the parent dichloride compound $\mathbf{1}$ (eq 5). Heterolytic cleavage is also observed upon interaction with excess $\mathrm{HBF}_{4}$ and $\mathrm{CF}_{3} \mathrm{COOD}$ in $\mathrm{C}_{6} \mathrm{D}_{6}$. The formation in these reactions of $\mathrm{CH}_{4}$ and $\mathrm{CH}_{3} \mathrm{D}$, respectively, was evidenced by ${ }^{1} \mathrm{H} \mathrm{NMR}$ spectroscopy.

$$
\mathrm{CpMo}\left(\eta^{4}-\mathrm{C}_{4} \mathrm{H}_{6}\right)\left(\mathrm{CH}_{3}\right)_{2}+2 \mathrm{HCl} \rightarrow \mathrm{CpMo}\left(\eta^{4}-\mathrm{C}_{4} \mathrm{H}_{6}\right) \mathrm{Cl}_{2}+2 \mathrm{CH}_{4}
$$

1

$\mathbf{2 a}$

The $\mathrm{CF}_{3} \mathrm{COOD}$ reaction allowed the observation of an EPR spectrum which is assigned to compound $\mathrm{CpMo}\left(\eta^{4}-\mathrm{C}_{4} \mathrm{H}_{6}\right)\left(\mathrm{O}_{2} \mathrm{CCF}_{3}\right)_{2}$. This compound was not isolated. However, the corresponding reaction of 2'a with $\mathrm{CF}_{3} \mathrm{COOD}$ has allowed the isolation and full characterization of a mixed methyl-trifluoroacetato derivative, $\mathbf{5}$, and a bis(trifluoroacetato) derivative, $\mathbf{6}$, by the use of 1 or 2 equiv of the acid, respectively (Scheme 2). An EPR monitoring of the reaction carried out with 2 equiv of acid clearly indicates that the first protonolysis process is much faster than the second one (see Figure 6). Analogously to the chloro system, the EPR signal of the mixed methyl trifluoroacetato derivative $(g=1.998)$ is shifted to high $g$ relative to the bis(trifluoroacetato) analogue $(g=1.982)$. The coupling pattern and $\mathrm{H}$ hyperfine splittings for 5 parallel those of the corresponding chloro analogue, namely, an apparent binomial octet, while 6 exhibits an apparent quintet pattern. 

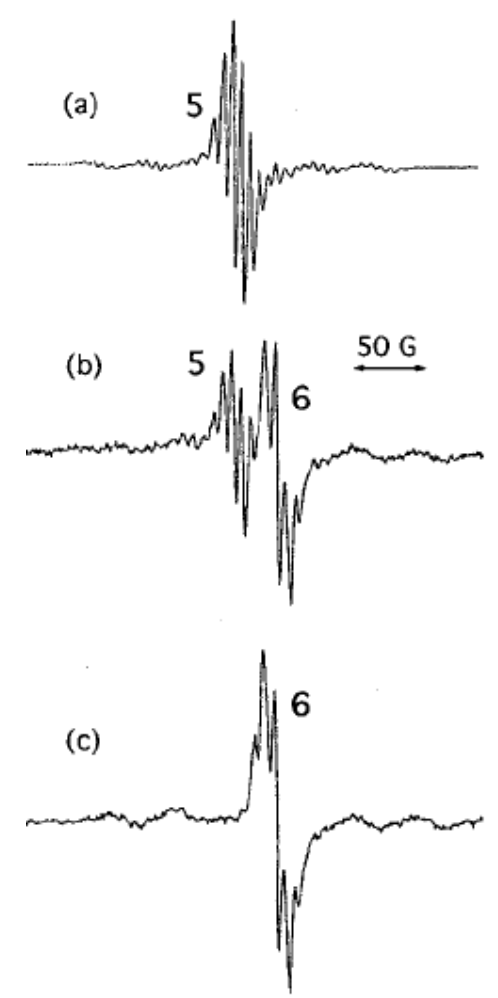

Figure 6. Room-temperature EPR spectra of a toluene solution obtained by mixing compounds 2'a and 2 equiv of $\mathrm{CF}_{3} \mathrm{COOD}$ : (a) immediately; (b) after $50 \mathrm{~min}$; (c) after $24 \mathrm{~h}$.

Compounds 5 and 6, like all other $\mathrm{CpMo}^{\mathrm{III}}\left(\eta^{4}\right.$-diene) derivatives described in this paper, exhibit a reduction wave in the cyclic voltammogram. The $E_{1 / 2}$ of this wave is shifted positively relative to the dimethyl parent system (see Table 3), each $\mathrm{Me} / \mathrm{O}_{2} \mathrm{CCF}_{3}$ substitution having quantitatively a similar effect as a $\mathrm{Me} / \mathrm{Cl}$ substitution. It is curious that the reduction wave of $\mathbf{5}$ is not fully reversible, the $\left(i_{\mathrm{a}} / i_{\mathrm{c}}\right)$ increasing with increasing scan speed $(0.43,0.50,0.61,0.65$, and 0.68 at 200, 500, 1000, 2000, and $5000 \mathrm{mV} / \mathrm{s}$, respectively), while the reduction waves of 2"a and 6 are fully reversible. In the corresponding chloride series, the dichloro, methyl chloro, and dimethyl complexes $(\mathbf{1}, \mathbf{3}$, and $\mathbf{2 a})$ all show reversible reduction processes.

Compound $\mathbf{6}$ could be obtained in the form of single crystals, which were investigated by X-ray diffraction. A view of the molecular structure is shown in Figure 7. The most interesting feature is the monodentate coordination for both trifluoroacetato ligands, confirming the indications given by the IR spectrum. Selected bond distances and angles are shown in Table 5. In comparison with the structure of compound 2"a, both the cyclopentadienyl ring and the diene ligand are closer to the metal center in compound 6, as shown by the Mo-CNT(1) and Mo$\mathrm{CNT}(2)$ distances, respectively. A greater effective positive charge on the metal center resulting 
from the replacement of the two methyl groups with the more electronegative trifluoroacetato ligands, thereby reducing the metal radius, may be held responsible for this difference. The diene relative arrangement shows a larger fold angle $\tilde{o}\left(95.91^{\circ}\right)$ and a larger negative $d(-0.155 \AA)$ relative to compound $\mathbf{2}$ 'a.

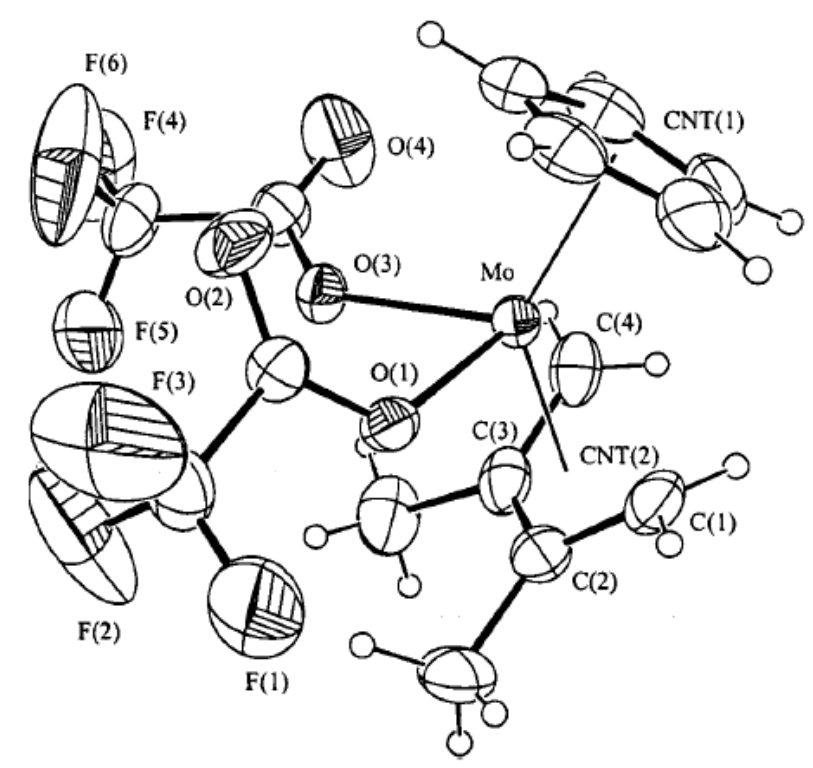

Figure 7. ORTEP ${ }^{89}$ view of compound 6 with thermal ellipsoids drawn at the $30 \%$ probability level.

Table 5. Selected Bond Distances $(\AA)$ and Angles (deg) for Compound $\mathbf{6}^{\mathbf{a}}$

\begin{tabular}{llll}
\hline Mo-CNT(1) & $1.982(5)$ & Mo-C(1) & $2.206(4)$ \\
Mo-CNT(2) & $1.918(5)$ & Mo-C(2) & $2.370(4)$ \\
Mo-O(1) & $2.102(3)$ & Mo-C(3) & $2.355(4)$ \\
Mo-O(3) & $2.092(3)$ & Mo-C(4) & $2.209(4)$ \\
CNT(1)-Mo-CNT(2) & $133.2(7)$ & CNT(2)-Mo-O(1) & $98.7(3)$ \\
CNT(1)-Mo-O(1) & $115.6(4)$ & CNT(2)-Mo-O(3) & $99.4(3)$ \\
CNT(1)-Mo-O(3) & $117.0(4)$ & O(1)-Mo-O(3) & $78.84(11)$ \\
\hline
\end{tabular}

${ }^{a} \mathrm{CNT}(1)$ is the center of gravity of the cyclopentadienyl ring [atoms $\left.\mathrm{C}(7)-\mathrm{C}(11)\right]$. CNT(2) is the center of gravity of the butadiene ligand [atoms $\mathrm{C}(1)-\mathrm{C}(4)$ ].

\section{Conclusion}

The alkylation of $\mathrm{CpMo}\left(\eta^{4}\right.$-diene $) \mathrm{Cl}_{2}$ compounds has permitted the isolation and characterization of the first examples of stable radical complexes of Mo(III) containing alkyl ligands. The Mo-R bonds in these derivatives are relatively robust, their homolytic cleavage being observed only under photolytic activation at ambient temperature or above. This is somewhat surprising, because the corresponding decomposition in the related 
$\mathrm{CpMo}\left(\mathrm{CH}_{3}\right)_{2}\left(\mathrm{PMe}_{3}\right)_{2}$ compound occurs spontaneously below room temperature. ${ }^{15}$ How the nature of the neutral ligands (one diene vs two $\mathrm{PMe}_{3}$ ) affects the stability and homolytic reactivity of these bonds is not currently understood. Preliminary density functional theory studies on $\mathrm{CpMo}\left(\eta^{4}\right.$-diene $)\left(\mathrm{CH}_{3}\right)_{2}$ and on the model system $\mathrm{CpMo}\left(\mathrm{CH}_{3}\right)_{2}\left(\mathrm{PH}_{3}\right)_{2}$ indicate that the strength of the $\mathrm{Mo}-\mathrm{CH}_{3}$ bond is not significantly altered by the nature of the neutral ligands, suggesting that the decomposition mechanism may be more complex that a simple Mo-R bond homolysis. Further studies both at the experimental and at the theoretical level will be devoted to throwing light on this phenomenon. We are also further pursuing reactivity studies of this new class of alkyl derivatives.

\section{Experimental Section}

General Procedures. All reactions involving air- and moisture-sensitive organometallic compounds were carried out in a Jacomex glovebox or by the use of standard Schlenck techniques under an argon atmosphere. Toluene and diethyl ether were purified by distillation under argon after drying over sodium benzophenone ketyl. THF was dried over sodium benzophenone ketyl and then over $\mathrm{Na} / \mathrm{K}$ alloy. Pentane was dried over sodium. 1H NMR measurements were carried out on a Bruker AC200 spectrometer. The peak positions are reported with positive shifts in ppm downfield of TMS as calculated from the residual solvent peaks. The IR spectra were recorded on a Bruker IFS 66V spectrophotometer with $\mathrm{NaCl}$ optics. EPR measurements were carried out at the X-band microwave frequency on a Bruker ESP 300 spectrometer, equipped with a ER 4111 VT unit. The spectrometer was calibrated with DPPH ( $g$ 2.0037). EPR spectra simulations and fittings were carried out with WinSim.77 Cyclic voltamograms were recorded with an EG\&G 362 potentiostat connected to a Macintosh computer through MacLab hardware/software. The electrochemical cell is a locally modified Schlenk tube. The cell is fitted with a Pt counter electrode, a $\mathrm{Ag} / \mathrm{AgCl}$ reference electrode, and a Pt working electrode. $\mathrm{Bu}_{4} \mathrm{NPF}_{6}$ was used as supporting electrolyte at a concentration of $0.1 \mathrm{M}$. All potentials are reported vs the $\mathrm{Cp}_{2} \mathrm{Fe} / \mathrm{Cp}_{2} \mathrm{Fe}^{+}$couple, which was introduced under argon into the cell at the end of each measurement. All the voltammetric results obtained in this study are collected in Table 3. Elemental analyses were performed with a Fisons EA 1108 apparatus. Isoprene and 2,3-dimethylbutadiene were purchased from Aldrich Chemical Co, degassed, and 
stored on $4 \AA$ molecular sieves before use. $\mathrm{CH}_{3} \mathrm{MgBr}\left(3.0 \mathrm{M}\right.$ in $\left.\mathrm{Et}_{2} \mathrm{O}\right), \mathrm{CD}_{3} \mathrm{MgI}\left(1 \mathrm{M}\right.$ in $\left.\mathrm{Et}_{2} \mathrm{O}\right)$, $\left(\mathrm{CH}_{3}\right)_{3} \mathrm{SiCH}_{2} \mathrm{MgCl}\left(1 \mathrm{M}\right.$ in $\left.\mathrm{Et}_{2} \mathrm{O}\right)$, and $\left(\mathrm{C}_{6} \mathrm{H}_{2} \mathrm{Me}_{3}-2,4,6\right) \mathrm{MgBr}(1 \mathrm{M}$ in THF) were purchased from Aldrich Chemical Co. and used as received. Diethyl ether solutions of PhLi, PhMgI, and $\mathrm{PhCH}_{2} \mathrm{MgBr}^{78}$ and compounds $\left\{\mathrm{CpMoCl}_{2}\right\}_{n}{ }^{54}$ and $\mathrm{CpMo}\left(\eta^{4}-\mathrm{C}_{4} \mathrm{H}_{6}\right) \mathrm{Cl}_{2}(\mathbf{1})^{21}$ were prepared as described in the literature.

Synthesis of $\operatorname{CpMo}\left(\eta^{4}\right.$-diene $)$ Cl2. Diene = Isoprene, 1'. This synthetic procedure is an adaptation of that previously reported for compound $1 .^{21}\left\{\mathrm{CpMoCl}_{2}\right\}_{n}(2.216 \mathrm{~g} ; 9.55 \mathrm{mmol}$ of Mo) was suspended in $40 \mathrm{~mL}$ of THF. Isoprene $(1.05 \mathrm{~mL} ; 10.5 \mathrm{mmol})$ was added to the mixture via a syringe, followed by heating to $70{ }^{\circ} \mathrm{C}$ for $4 \mathrm{~h}$, yielding $\mathbf{1}^{\prime}$ as a fine red-brown powder. The suspension was concentrated to about half volume, followed by addition of pentane $(20 \mathrm{~mL})$. Following filtration, the solid was washed with pentane $(2 \times 10 \mathrm{~mL})$ and dried under vacuum. Yield: $2.222 \mathrm{~g}, 80 \%$. EPR (THF, room temperature): singlet, $g=1.994$ (cf. lit. ${ }^{18} 1.995$ ), $a_{\mathrm{Mo}}=$ 37.7 G. Anal. Calcd for $\mathrm{C}_{10} \mathrm{H}_{13} \mathrm{Cl}_{2} \mathrm{Mo}$ : C, 40,03; H, 4.37. Found: C, 40.11; H, 4.38.

Diene $=$ 2,3-dimethyl-1,3-butadiene, 1". A procedure similar to that described above for 1' yielded $4.512 \mathrm{~g}$ of $\mathbf{1}$ " (72\%) from $\left\{\mathrm{CpMoCl}_{2}\right\}_{n}(4.715 \mathrm{~g} ; 20.32 \mathrm{mmol}$ of $\mathrm{Mo})$ and 2,3dimethylbuta-1,3-diene (2.75 mL; $24 \mathrm{mmol})$ in $80 \mathrm{~mL}$ of THF. EPR (THF, room temperature): singlet, $g=1.994 ; a_{\mathrm{Mo}}=37.7 \mathrm{G}$. Anal. Calcd for $\mathrm{C}_{11} \mathrm{H}_{15} \mathrm{Cl}_{2} \mathrm{Mo}$ : C, 42.07; H, 4.81. Found: C, 42.08; H, 4.41.

Synthesis of $\mathbf{C p M o}\left(\boldsymbol{\eta}^{4}\right.$-diene $) \mathbf{R}_{2}$. The synthesis of all the dialkyl complexes was carried out under identical experimental conditions. The preparation of $\mathrm{CpMo}\left(\eta^{4}-\mathrm{C}_{4} \mathrm{H}_{6}\right)\left(\mathrm{CH}_{3}\right)_{2}(\mathbf{2 a})$ is described below as a representative example. To a suspension of 1 (534 mg, $1.86 \mathrm{mmol}$ ) in 30 $\mathrm{cm} 3$ of $\mathrm{Et} 2 \mathrm{O}$ at $-78{ }^{\circ} \mathrm{C}$ was added $1.4 \mathrm{~mL}$ of $\mathrm{MeMgBr}$ in $\mathrm{Et}_{2} \mathrm{O}$ (3.0 M, $4.1 \mathrm{mmol}$; Grignard/Mo = 2.2). The resulting mixture was stirred while being allowed to warm slowly to room temperature. During this time a white solid precipitated, while the red-brown solid dissolved to afford a green solution. The solvent was removed under reduced pressure, and the residue was extracted with pentane $(2 \times 20 \mathrm{~mL})$. The extracts were combined and filtered through a column of Celite $(1.5 \mathrm{x}$ $3 \mathrm{~cm}$ ). The column was washed with pentane until the washings were colorless. The solution was evaporated under reduced pressure to dryness, yielding compound $\mathbf{2 a}$ as a dark green powder. Yield: $232 \mathrm{mg}, 51 \%$. Anal. Calcd for $\mathrm{C}_{11} \mathrm{H}_{17} \mathrm{Mo}$ : C: 53.88; H, 6.99. Found: C, 53,73; H, 7.34. EPR spectrum (toluene, $-80{ }^{\circ} \mathrm{C}$ ): apparent undecet with Mo satellites; $g=2.012 ; a_{\mathrm{Mo}}=33.1 \mathrm{G}$; $a_{\mathrm{H}}=6.0 \mathrm{G}(2 \mathrm{H}) ; a_{\mathrm{H}}=5.4(6 \mathrm{H}) ; a_{\mathrm{H}}=4.9 \mathrm{G}(2 \mathrm{H})$. 
Compound 2a-d6: $57 \%$ yield from $5.2 \mathrm{mmol}$ of $\mathbf{1}$ and 2.2 equiv of $\mathrm{CD}_{3} \mathrm{MgI}$. EPR (pentane, $\left.-113{ }^{\circ} \mathrm{C}\right)$ : apparent broad quintet with Mo satellites; $g=2.012 ; a_{\mathrm{Mo}}=33.3 \mathrm{G} ; a_{\mathrm{H}}=6.3(2 \mathrm{H}) ; a_{\mathrm{H}}=$ $4.7 \mathrm{G}(2 \mathrm{H}) ; a_{\mathrm{D}}=0.41 \mathrm{G}(6 \mathrm{D})$.

Compound 2'a: $55 \%$ yield from $1.92 \mathrm{mmol}$ of $\mathbf{1}$ ' and 2.2 equiv of $\mathrm{CH}_{3} \mathrm{MgBr}$. Anal. Calcd for $\mathrm{C}_{12} \mathrm{H}_{19} \mathrm{Mo}$ : C, 55.6; H, 7.39. Found: C, 55.29; H, 7.50. EPR (pentane, $-80{ }^{\circ} \mathrm{C}$ ): apparent undecet with Mo satellites; $g=2.012 ; a_{\mathrm{Mo}}=33.0 \mathrm{G} ; a_{\mathrm{H}}=6.3 \mathrm{G}(2 \mathrm{H}) ; a_{\mathrm{H}}=5.2 \mathrm{G}(6 \mathrm{H}) ; a_{\mathrm{H}}=5.7$ (2H).

Compound 2"a: $62 \%$ yield from $3.0 \mathrm{mmol}$ of $\mathbf{1}$ " and 2.2 equiv of $\mathrm{CH}_{3} \mathrm{MgBr}$. Anal. Calcd for $\mathrm{C}_{13} \mathrm{H}_{21} \mathrm{Mo}$ : C, 57.14; H, 7.75. Found: C, 56.99; H, 7.75. EPR (pentane, $-80{ }^{\circ} \mathrm{C}$ ): apparent undecet with molybdenum satellites; $g$ ) $2.013 ; a_{\mathrm{Mo}}=32.9 \mathrm{G} ; a_{\mathrm{H}}=6.6 \mathrm{G}(2 \mathrm{H}) ; a_{\mathrm{H}}=5.5 \mathrm{G}(6 \mathrm{H})$; $a_{\mathrm{H}}=5.3 \mathrm{G}(2 \mathrm{H})$.

Compound 2b: $51 \%$ yield from $1.8 \mathrm{mmol}$ of 1 and 2.2 equiv of $\mathrm{PhCH} 2 \mathrm{MgBr}$. Anal. Calcd for $\mathrm{C}_{23} \mathrm{H}_{25} \mathrm{Mo}$ : C, 69.52; H, 6.34. Found: C, 69.47; H, 6.63. EPR (pentane, $-80{ }^{\circ} \mathrm{C}$ ): multiplet with molybdenum satellites; $g=2.012 ; a_{\mathrm{Mo}}=33.5 \mathrm{G} ; a_{\mathrm{H}}=6.3 \mathrm{G}(2 \mathrm{H}) ; a_{\mathrm{H}}=6.0 \mathrm{G}(2 \mathrm{H}) ; a_{\mathrm{H}}=5.9$ $\mathrm{G}(2 \mathrm{H}) ; a_{\mathrm{H}}=4.7 \mathrm{G}(2 \mathrm{H})$.

Compound 2"b: $48 \%$ yield from $1.1 \mathrm{mmol}$ of $\mathbf{1}$ " and 2.2 equiv of $\mathrm{PhCH}_{2} \mathrm{MgBr}$. Anal. Calcd for $\mathrm{C}_{25} \mathrm{H}_{29} \mathrm{Mo}$ : C, 70.58; H, 6.87. Found: C, 70.42; H, 7.12. EPR (pentane, $-80{ }^{\circ} \mathrm{C}$ ): multiplet with molybdenum satellites; $g=2.013 ; a_{\mathrm{Mo}}=33.2 \mathrm{G} ; a_{\mathrm{H}}=6.0 \mathrm{G}(2 \mathrm{H}) ; a_{\mathrm{H}}=5.9 \mathrm{G}$ $(2 \mathrm{H}) ; a_{\mathrm{H}}=5.7 \mathrm{G}(2 \mathrm{H}) ; a_{\mathrm{H}}=5.4 \mathrm{G}(2 \mathrm{H})$.

Compound 2c: $45 \%$ yield from $5.5 \mathrm{mmol}$ of $\mathbf{1}$ and 2.2 equiv of $\left(\mathrm{CH}_{3}\right)_{3} \mathrm{SiCH}_{2} \mathrm{MgCl}$. The compound was obtained as dark green needles by cooling a pentane solution at $-80{ }^{\circ} \mathrm{C}$ for $48 \mathrm{~h}$. Anal. Calcd for $\mathrm{C}_{17} \mathrm{H}_{33} \mathrm{Si}_{2} \mathrm{Mo:}$ C, 52.41; H, 8.54. Found: C, 52.17; H, 8.56. EPR (pentane, -80 $\left.{ }^{\circ} \mathrm{C}\right)$ : multiplet with Mo satellites; $g=2.009 ; a_{\mathrm{Mo}}=34.3 \mathrm{G} ; a_{\mathrm{H}}=6.5 \mathrm{G}(2 \mathrm{H}) ; a_{\mathrm{H}}=6.0 \mathrm{G}(2 \mathrm{H}) ; a_{\mathrm{H}}$ $=4.4 \mathrm{G}(2 \mathrm{H}) ; a_{\mathrm{H}}=3.5 \mathrm{G}(2 \mathrm{H})$.

Compound 2"c: $44 \%$ yield from $1.5 \mathrm{mmol}$ of 1 " and 2.2 equiv of $\left(\mathrm{CH}_{3}\right)_{3} \mathrm{SiCH}_{2} \mathrm{MgCl}$. The compound was obtained as dark green needles by cooling a pentane solution at $-80{ }^{\circ} \mathrm{C}$ for $48 \mathrm{~h}$. Anal. Calcd for $\mathrm{C}_{19} \mathrm{H}_{37} \mathrm{Si}_{2} \mathrm{Mo}$ : C, 54.65; H, 8.93. Found: C, 55.05; H, 9.09. EPR (pentane, -80 $\left.{ }^{\circ} \mathrm{C}\right)$ multiplet with Mo satellites; $g=2.010 ; a_{\mathrm{Mo}}=33.6 \mathrm{G} ; a_{\mathrm{H}}=6.4 \mathrm{G}(2 \mathrm{H}) ; a_{\mathrm{H}}=5.9 \mathrm{G}(2 \mathrm{H}) ; a_{\mathrm{H}}=$ $4.5 \mathrm{G}(2 \mathrm{H}) ; a_{\mathrm{H}}=3.4 \mathrm{G}(2 \mathrm{H})$.

Arylation Reactions. Reactions between compounds 1 and 1" and $\mathrm{PhLi}, \mathrm{PhMgBr}$, or $\left(\mathrm{C}_{6} \mathrm{H}_{2} \mathrm{Me}_{3}-2,4,6\right) \mathrm{MgBr}$ were carried out under conditions similar to those described above for the 
alkylation reactions. The resulting solutions are extremely sensitive, and attempts to recover pure solid materials from these solutions failed. EPR (pentane, $-80^{\circ} \mathrm{C}$ ): product of the 1-PhLi or PhMgBr reaction: apparent quintet with Mo satellites; $g=2.009 ; a_{\mathrm{Mo}}=32.4 \mathrm{G} ; a_{\mathrm{H}}=6.3 \mathrm{G}(2 \mathrm{H})$; $a_{\mathrm{H}}=5.2 \mathrm{G}(2 \mathrm{H})$; product of the 1 "- $\mathrm{PhLi}$ or $\mathrm{PhMgBr}$ reaction: apparent quintet with Mo satellites; $g=2.009 ; a_{\mathrm{Mo}}=32.3 \mathrm{G} ; a_{\mathrm{H}}=6.3 \mathrm{G}(2 \mathrm{H}) ; a_{\mathrm{H}}=5.1 \mathrm{G}(2 \mathrm{H})$; product of the $1^{\prime \prime}-\left(\mathrm{C}_{6} \mathrm{H}_{2} \mathrm{Me}_{3-}\right.$ 2,4,6) $\mathrm{MgBr}$ reaction: apparent quintet with Mo satellites; $g=2.010 ; a_{\mathrm{Mo}}=32.4 \mathrm{G} ; a_{\mathrm{H}}=6.1 \mathrm{G}$ $(2 \mathrm{H}) ; a_{\mathrm{H}}=5.2 \mathrm{G}(2 \mathrm{H})$. Crystallization of the product of the $1 \% / m e s i t y l$ Grignard reaction by diffusion of pentane into a concentrated THF solution at room temperature provided crystals of compound 4".

Synthesis of $\mathbf{C p M o}\left(\boldsymbol{\eta}^{4}-\mathbf{C}_{4} \mathbf{H}_{6}\right) \mathbf{C I M e}$ 3. To a stirred, brown suspension of $\mathbf{1}$ (858 $\mathrm{mg}, 3$ mmol) in THF $(40 \mathrm{~mL})$ at $-80{ }^{\circ} \mathrm{C}$ was added dropwise $\mathrm{CH}_{3} \mathrm{MgCl}$ in Et2O (1.1 mL, 3.0 M, 3.2 mmol) via a syringe. After the addition of the Grignard reagent, the reaction mixture was stirred for $4 \mathrm{~h}$ while being allowed to warm slowly to room temperature. During this time a clear solid precipitated, while the red-brown solid dissolved to afford a green solution. The solvent was removed in vacuo, and the residue was extracted with pentane $(60 \mathrm{~mL})$. The extract was filtered through Celite $(1.5 \times 2 \mathrm{~cm})$. The pentane was removed from the filtrate under reduced pressure to obtain 3 as a dark green powder. Yield: $550 \mathrm{mg}$, 69\%. Anal. Calcd for $\mathrm{C}_{10} \mathrm{H}_{14} \mathrm{ClMo}$ : C, 45.22; H, 5.31. Found: C, 45.22; H, 5.63. EPR (toluene, room temperature): apparent octet with Mo satellites, $g=2.012 ; a_{\mathrm{Mo}}=32.8 \mathrm{G} ; a_{\mathrm{H}}=6.4 \mathrm{G}(2 \mathrm{H}) ; a_{\mathrm{H}}=5.4 \mathrm{G}(3 \mathrm{H}) ; a_{\mathrm{H}}=4.5 \mathrm{G}(2 \mathrm{H})$. In a separate preparative experiment, a concentrated pentane solution of the product $\mathbf{3}$ was set for crystallization at room temperature without protection from light. Single crystals of compound 4 which were suitable for an X-ray analysis formed over 1 week.

Formation of 3 by Ligand Redistribution from 1 and 2a. A solution of $2 \mathbf{a}(78 \mathrm{mg}, 0.31$ $\mathrm{mmol})$ in $10 \mathrm{~mL}$ of THF was cannulated onto a suspension of 1 (90 mg, $0.31 \mathrm{mmol})$ in $40 \mathrm{~mL}$ of THF at room temperature. The mixture was then protected from light and stirred for 3 weeks. Aliquots from this mixture were withdrawn from time to time by cannula directly into an electrochemical cell which already contained THF and supporting electrolyte for a monitoring of the reaction by cyclic voltammetry (see Results section).

Attempt to React Compound 2a with Lewis Bases. (a) With CO. Compound 2a (187 $\mathrm{mg}, 0.76 \mathrm{mmol})$ was dissolved in THF $(80 \mathrm{~mL})$. An initial EPR spectrum was recorded. The solution was introduced into a 0.5 L Parr autoclave and pressurized with CO (600 psi). The 
solution was stirred at room temperature overnight. An aliquot the solution was withdrawn and exhibited no change in color and intensity of the EPR spectrum. No $v(\mathrm{C}=\mathrm{O})$ could be observed by IR. The autoclave was then depressurized to $400 \mathrm{psi}$ and warmed to $65{ }^{\circ} \mathrm{C}$ for $1 \mathrm{~h}$ (the pressure increased again to ca. 600 psi). No change in the properties of the solution was again observed.

(b) With PMe3. Compound 2a (166 mg, $0.66 \mathrm{mmol})$ was dissolved in THF (20 mL). PMe3 ( $1 \mathrm{M}$ in THF, $0.8 \mathrm{~mL}, 0.8 \mathrm{mmol}$ ) was added by syringe, and the resulting solution was stirred at room temperature for $24 \mathrm{~h}$. The EPR spectrum showed no decrease in intensity relative to the initial solution.

(c) With PEt 3 . Compound 2a (90 mg, $0.36 \mathrm{mmol})$ was dissolved in THF (10 mL). PEt3 (1 $\mathrm{M}$ in THF, $0.5 \mathrm{~mL}, 0.5 \mathrm{mmol}$ ) was added by syringe, and the resulting solution was heated to reflux under stirring for $24 \mathrm{~h}$. The EPR spectrum showed no decrease in intensity relative to the initial solution.

Reaction of Complex 2a with Brønsted Acids. (a) With HBF4. In a NMR tube, a solution of $\mathbf{2 a}(46 \mathrm{mg}, 0.19 \mathrm{mmol})$ in $0.5 \mathrm{~mL}$ of $\mathrm{C}_{6} \mathrm{D}_{6}$ was prepared. $\mathrm{HBF}_{4} \cdot \mathrm{OEt}_{2}(54 \%, 24 \mu \mathrm{L}$, $0.17 \mathrm{mmol}$ ) was then added via a microsyringe. A dark precipitate immediately formed while gas evolution was noted. The ${ }^{1} \mathrm{H}$ NMR spectrum revealed the formation of $\mathrm{CH}_{4}(\delta=0.15 \mathrm{ppm})$, while an EPR spectrum of the surpernatant solution was featureless.

(b) With CF3COOD. In an NMR tube, a solution of $2 \mathbf{a}(10 \mathrm{mg}, 0.04 \mathrm{mmol})$ in $0.5 \mathrm{~mL}$ of $\mathrm{C}_{6} \mathrm{D}_{6}$ was prepared. An excess $(20 \mu \mathrm{L}, 0.26 \mathrm{mmol})$ of $\mathrm{CF}_{3} \mathrm{COOD}$ was then added via a microsyringe. The color immediately changed from dark green to yellow-brown. The ${ }^{1} \mathrm{H}$ NMR spectrum revealed the formation of $\mathrm{CH}_{3} \mathrm{D}\left(\mathrm{t}, \delta=0.14 \mathrm{ppm},{ }^{2} J_{\mathrm{HD}}=0.2 \mathrm{~Hz}\right)$. No other resonances were noticed except for those of the solvent. The EPR spectrum of this solution showed a broad singlet $\left(g=1.985 ; a_{\mathrm{Mo}}=41 \mathrm{G}\right)$. Identical results were obtained upon reacting compound 2'a with $\mathrm{CF}_{3} \mathrm{COOD}$ under the same conditions.

(c) With HCl in THF. In a Schlenk tube, a solution of $\mathbf{2 a}(17 \mathrm{mg}, 0.07 \mathrm{mmol})$ in $10 \mathrm{~mL}$ of THF was prepared. Through this solution was bubbled via a Pasteur pipet an excess amount of gaseous $\mathrm{HCl}$ (generated in situ in a separate Schlenk tube by adding a $37 \% \mathrm{HCl}$ solution to $\mathrm{P}_{4} \mathrm{O}_{10}$ ). An immediate color change from green to brown was observed. Bubbling was stopped and the solution was stirred at room temperature for $4 \mathrm{~h}$ under the $\mathrm{HCl}$-containing atmosphere. 
The combined EPR and cyclic voltammetric analysis of the final solution showed the conversion to compound 1.

(d) With Other Brønsted Acids. Various THF solutions of compound 2a were treated with excess amounts of other acids $\left(\mathrm{H}_{2} \mathrm{O}, \mathrm{MeOH}, \mathrm{CH}_{3} \mathrm{COOH}, \mathrm{H}_{3} \mathrm{PO}_{4}, \mathrm{H}_{3} \mathrm{O}^{+}\right.$, the latter corresponding to a ca. $1 \mathrm{M}$ aqueous $\mathrm{HCl}$ solution) as described in the previous two sections. EPR spectroscopic monitoring over $1 \mathrm{~h}$ revealed no new signals and a reduction of EPR intensity of the initial signal by less than $10 \%$ in all cases.

Synthesis of $\mathbf{C p M o}\left(\boldsymbol{\eta}^{4}-\mathbf{C}_{6} \mathbf{H}_{10}\right)\left(\mathbf{C H}_{3}\right)\left(\mathbf{O C O C F}_{3}\right)$, 5. One equivalent $(34 \mu \mathrm{L}, 0.44 \mathrm{mmol})$ of $\mathrm{CF}_{3} \mathrm{COOD}$ was slowly added by microsyringe to a vigorously stirred solution of 2"a (122 mg, $0.44 \mathrm{mmol}$ ) in $10 \mathrm{~mL}$ of toluene. The green color turned immediately yellow-brown. This solution was stirred for one additional hour, and the solvent was removed in vacuo. A dark yellow powder was obtained. The compound was recrystallized by cooling a saturated pentane solution to $-80{ }^{\circ} \mathrm{C}$. Yield: $147 \mathrm{mg}, 90 \%$. Anal. Calcd for $\mathrm{C}_{14} \mathrm{H}_{18} \mathrm{O}_{2} \mathrm{~F}_{3} \mathrm{Mo}$ : C, 45.30; H, 4.89. Found: C, 45.14; H, 5.02. IR (Nujol mull, cm-1): 1685 [s, br, v(CO)], 1190 [s, v(CO)], 1138 [s, $v(\mathrm{CO})]$. EPR (toluene, room temperature): apparent octet with Mo satellites, $g=1.998$; $a_{\mathrm{Mo}}=$ $40.6 \mathrm{G} ; a_{\mathrm{H}}=7.0 \mathrm{G}(2 \mathrm{H}) ; a_{\mathrm{H}}=5.6 \mathrm{G}(2 \mathrm{H}) ; a_{\mathrm{H}}=5.4 \mathrm{G}(3 \mathrm{H})$.

Synthesis of $\mathbf{C p M o}\left(\eta^{4}-\mathbf{C}_{6} \mathbf{H}_{10}\right)\left(\mathrm{OCOCF}_{3}\right)$, 6. To a green solution of 2"a (143 mg, 0.52 $\mathrm{mmol})$ in toluene $(20 \mathrm{~mL})$ was added $\mathrm{CF}_{3} \mathrm{COOD}(88 \mu \mathrm{L}, 1.15 \mathrm{mmol})$ via a microsyringe. The evolution of gas could be observed, while the solution immediately turned yellow-brown and then slowly yellow. After stirring for $8 \mathrm{~h}$ at room temperature, the solvent was removed in vacuo to yield a dark yellow powder, which was washed with pentane. Yield: $212 \mathrm{mg}$, 87\%. Anal. Calcd for $\mathrm{C}_{15} \mathrm{H}_{15} \mathrm{O}_{4} \mathrm{~F}_{6} \mathrm{Mo}$ : C, 38.40; H, 3.22 Found: C, 38.66; H, 3.23. IR (Nujol mull, $\mathrm{cm}^{-1}$ ): 1700 [s, br., v(CO)], 1192 [s, v(CO)], 1143 [s, v(CO)]. EPR (toluene, room temperature): apparent quintet with Mo satellites, $g=1.982 ; a_{\mathrm{Mo}}=40.6 \mathrm{G} ; a_{\mathrm{H}}=7.7 \mathrm{G}(2 \mathrm{H}) ; a_{\mathrm{H}}=5.8 \mathrm{G}(2 \mathrm{H})$. A single crystal for the X-ray analysis was obtained by slow diffusion of pentane into a THF solution at room temperature.

X-ray Crystallography. Crystal data and refinement figures for all compounds are reported in Table 6.

(a) Compound 2"a. A dark green crystal $\left(0.32 \times 0.30 \times 0.25 \mathrm{~mm}^{3}\right)$ was placed in a flamesealed capillary under Ar and mounted on an Enraf-Nonius CAD4 diffractometer. A total of 4687 reflections (of which 4561 were unique) were collected at room temperature up to $\sin (\theta) / \lambda=0.63$ 
$\AA^{-1}$. The data were corrected for Lorentz and polarization effects and for absorption (psi-scan method). ${ }^{79,80}$ A $12.5 \%$ decay was linearly corrected. The structure was solved via a Patterson search program ${ }^{81}$ and refined (space group $P 21 / c$ ) with full-matrix least-squares methods ${ }^{81}$ based on $\left|F^{2}\right|$. All non-hydrogen atoms were refined with anisotropic thermal parameters. Hydrogen atoms of the cyclopentadienyl anion were included in their calculated positions and refined with a riding model. The methyl hydrogen atoms were located in the Fourier difference map and refined, after idealization, as rigid rotating groups. The hydrogen atoms attached to the butadiene ligand were located in the Fourier difference map and were refined freely. At the end of this refinement the agreement indices were $w R 2=0.0747$ for all data and $\mathrm{R} 1=0.0276$ for 4053 intensities with $I>2 \sigma(I)$. The final difference electron density is featureless: $\Delta \rho=0.33$ and -0.53 e $\AA^{-3}$.

(b) Compound 4. A brown crystal $\left(0.36 \times 0.28 \times 0.25 \mathrm{~mm}^{3}\right)$ was mounted on an EnrafNonius CAD4 diffractometer. A total of 1920 reflections (1827 unique) were collected up to $\sin (\theta) / \lambda=0.62 \AA^{-1}$. The data were corrected for Lorentz and polarization effects and for absorption (psi-scan method). ${ }^{79,80}$ The structure was solved via a Patterson search program ${ }^{81}$ and refined (space group P21/c) with full-matrix least-squares methods based on $\left|F^{2}\right|$. All nonhydrogen atoms were refined with anisotropic thermal parameters. The cyclopentadienyl ring was refined as a variable metric group. Except for the $\mathrm{CH}_{2}$ hydrogen atoms of the butadiene ligand, which were located on the difference Fourier map, all the hydrogen atoms were included in their calculated positions. All $\mathrm{H}$ atoms were refined with a riding model. The final agreement indices were $\mathrm{wR} 2=0.140$ for all data and R1 $=0.046$ for 1639 intensities with $I>2 \sigma(I)$. Final difference electron density: $\Delta \rho=1.0$ and -0.59 e $\AA^{-3}$.

(c) Compound 4". A green crystal $\left(0.17 \times 0.15 \times 0.12 \mathrm{~mm}^{3}\right)$ suitable for an X-ray analysis was mounted on an Enraf-Nonius KappaCCD using Mo KR radiation, and 29175 reflections (4810 unique) were collected up to $\sin (\theta) / \lambda=0.807$ at $110 \mathrm{~K}$. Absorption correction was applied to the data during integration by the SCALEPACK ${ }^{82}$ algorithm. The structure was solved via a Patterson search program ${ }^{81}$ and refined (space group $\mathrm{Pbcm}$ ) with full-matrix least-squares methods based on $\left|F^{2}\right|$. Except for the chlorine atom, all non-hydrogen atoms were refined with anisotropic thermal parameters. Hydrogen atoms were found by Fourier difference synthesis and freely refined with isotropic temperature factors fixed to 1.3 times those of the corresponding carbon atoms. The halide atom position was found to be compositionally disordered. Two positions were independently refined as $\mathrm{Br}$ and $\mathrm{Cl}$ with no constraints except that the sof's were 
imposed as $x$ and $(1-x)$, respectively, with $x$ refining to 0.77 . The $\mathrm{Cl}$ atom was isotropically refined. The Mo-X distances are consistent with a Mo- $(\mu-\mathrm{Br})$ and a $\mathrm{Mo}-(\mu-\mathrm{Cl})$. The final agreement indices were $w R 2=0.0641$ for all data and R1 $=0.0368$ for 4230 intensities with $I>$

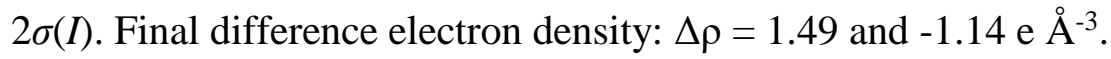

(d) Compound 6. A dichroic green-yellow crystal $\left(0.50 \times 0.35 \times 0.20 \mathrm{~mm}^{3}\right)$ was placed in a flame-sealed capillary under Ar and mounted on an Enraf-Nonius CAD4 diffractometer. A total of 3964 reflections (3633 unique) were collected at room temperature up to $\sin (\theta) / \lambda=0.62 \AA^{-1}$. The data were corrected for Lorentz and polarization effects and for absorption (psiscan method). ${ }^{79,80}$ A 7\% decay was linearly corrected. The structure was solved via a Patterson search program $^{3}$ and refined (space group $\mathrm{Pbca}$ ) with full-matrix least-squares methods81 based on $\mathrm{j} F 2 \mathrm{j}$. All non hydrogen atoms were refined with anisotropic thermal parameters. Hydrogen atoms of the cyclopentadienyl anion were included in their calculated positions and refined with a riding model. The methyl hydrogen atoms were located in the Fourier difference map and refined, after idealization, as rigid rotating groups. The hydrogen atoms attached to the butadiene ligand were located in the Fourier difference map and were refined freely. At the end of the refinement the thermal ellipsoids of the fluorine atoms were quite large and indicated either a disorder on the fluorine atom positions or very pronounced thermal librations. Any attempt to impose a disorder model lowered the agreement indices but did not lead to reasonable structural parameters. The final agreement indices were $\mathrm{wR} 2=0.113$ for all data and $\mathrm{R} 1=0.042$ for 2727 intensities with $I>2 \sigma(I)$. The final difference electron density is featureless: $\Delta \rho=0.79$ and -0.55 e $\AA^{-3}$. Crystal data are reported in Table 6.

Table 6. Crystal and Structure Refinement Data

\begin{tabular}{lllll}
\hline & 2"a & $\mathbf{4}$ & $\mathbf{4}$ & $\mathbf{6}$ \\
\hline formula & $\mathrm{C}_{13} \mathrm{H}_{21} \mathrm{Mo}$ & $\mathrm{C}_{18} \mathrm{H}_{22} \mathrm{Cl}_{2} \mathrm{Mo}_{2}$ & $\mathrm{C}_{22} \mathrm{H}_{30} \mathrm{Br}_{1.54} \mathrm{Cl}_{0.46} \mathrm{Mo}_{2}$ & $\mathrm{C}_{15} \mathrm{H}_{15} \mathrm{~F}_{6} \mathrm{MoO}_{4}$ \\
$\mathrm{M}$ & 273.24 & 501.14 & 625.76 & 469.21 \\
$T ; \mathrm{K}$ & $293(2)$ & $293(2)$ & $110(2)$ & $293(2)$ \\
diffractometer & $\mathrm{CAD} 4$ & $\mathrm{CAD} 4$ & Kappa CCD & CAD4 \\
cryst syst & monoclinic & monoclinic & orthorhombic & orthorhombic \\
space group & $P 21 / c$ & $P 21 / c$ & $P b c m$ & $P b c a$ \\
$a ; \AA$ & $15.092(1)$ & $10.636(1)$ & $8.7030(2)$ & $14.566(1)$ \\
$b ; \AA$ & $7.458(1)$ & $7.635(1)$ & $19.5210(3)$ & $14.717(1)$ \\
$c ; \AA$ & $22.186(2)$ & $11.912(1)$ & $12.4410(3)$ & $16.700(1)$ \\
$\beta ;$ deg & $91.248(8)$ & $111.454(6)$ & & 8 \\
$Z$ & 8 & 2 & 4 & 1864 \\
$F(000)$ & 1128 & 496 & 1.966 & 1.741 \\
$D$ calc; g/cm & 1.454 & 1.849 & 0.71073 & 0.71073 \\
$\lambda ; \AA$ & 0.71073 & 0.71073 & 4.16 & 0.809 \\
$\mu ;$ mm & 1.013 & 1.683 & $0.17 \times 0.15 \times 0.12$ & $0.50 \times 0.35 \times 0.20$
\end{tabular}




\begin{tabular}{|c|c|c|c|c|}
\hline $\sin (\theta) / \lambda \max ; \AA^{-1}$ & 0.63 & 0.62 & 0.807 & 0.62 \\
\hline \multirow[t]{3}{*}{ index ranges } & $h:-18 ; 18$ & $h:-13 ; 12$ & $h:-14 ; 13$ & $h:-18 ; 0$ \\
\hline & $k: 0 ; 9$ & $k: 0 ; 9$ & $k:-30 ; 31$ & $k:-18 ; 0$ \\
\hline & $l: 0 ; 27$ & $l: 0 ; 14$ & $l:-20 ; 19$ & $l:-20 ; 0$ \\
\hline decay; $\%$ & 12.5 & 2 & -7 & \\
\hline abs corr & psi-scan $85.9 \%-100 \%$ & psi-scan $90.5 \%-99.6 \%$ & SCALEPACK & psi-scan $96.1 \%-99.2 \%$ \\
\hline $\mathrm{RC}=$ reflns collec & 4687 & 1914 & 29175 & 3964 \\
\hline $\mathrm{IRC}=$ unique $\mathrm{RC}$ & $4561[R(\mathrm{int})) 0.027]$ & $1821[R(\mathrm{int})) 0.038]$ & $4810[R(\mathrm{int})) 0.034]$ & $3633[R(\mathrm{int})) 0.014]$ \\
\hline IRCGT $=\mathrm{IRC}$ and $[I>2 \sigma(I)]$ & 4053 & 1639 & 4230 & 2727 \\
\hline refinement method & \multicolumn{4}{|c|}{ full-matrix least squares on $F 2$} \\
\hline no. of data/restr/params & $4561 / 0 / 285$ & $1821 / 0 / 106$ & $4810 / 0 / 1753$ & $632 / 0 / 237$ \\
\hline$R$ for IRCGT & $\begin{array}{l}\mathrm{R} 1^{a}=0.028 \\
\mathrm{wR} 2^{b}=0.073\end{array}$ & $\begin{array}{l}\mathrm{R} 1^{a}=0.046 \\
\mathrm{wR} 2^{b}=0.135\end{array}$ & $\begin{array}{l}\mathrm{R} 1^{a}=0.029 \\
\mathrm{wR} 2^{b}=0.0641\end{array}$ & $\begin{array}{l}\mathrm{R} 1^{a}=0.042 \\
\mathrm{wR} 2^{b}=0.113\end{array}$ \\
\hline$R$ for IRC & $\begin{array}{l}\mathrm{R} 1^{a}=0.033 \\
\mathrm{wR} 2^{b}=0.075\end{array}$ & $\begin{array}{l}\mathrm{R} 1^{a}=0.053 \\
\mathrm{wR} 2^{b}=0.140\end{array}$ & $\begin{array}{l}\mathrm{R} 1^{a}=0.0368 \\
\mathrm{wR} 2^{b}=0.0671\end{array}$ & $\begin{array}{l}\mathrm{R} 1^{a}=0.065 \\
\mathrm{wR} 2^{b}=0.130\end{array}$ \\
\hline goodness-of-fit ${ }^{c}$ & 1.063 & 1.115 & 1.079 & 1.033 \\
\hline largest $\Delta \rho ; \mathrm{e}^{-3}$ & 0.331 and -0.532 & 1.551 and -0.921 & 1.495 and -1.143 & 0.789 and -0.549 \\
\hline
\end{tabular}

Computational Details. All electronic structure and geometry optimization calculations were performed using GAUSSIAN $94^{83}$ on an SGI Origin 200 workstation. The LanL2DZ set was employed to perform geometry optimizations with a density functional theory (DFT) approach. The B3LYP functional (B3LYP = the three-parameter form of the Becke, Lee, Yang, and Parr functional $)^{84}$ was employed. The LanL2DZ basis set includes both Dunning and Hay's D95 sets for $\mathrm{H}$ and $\mathrm{C}^{85}$ and the relativistic core potential sets of Hay and Wadt for the heavy atoms. ${ }^{86-88}$ Electrons outside the core were all those for $\mathrm{H}$ and $\mathrm{C}$, the $4 \mathrm{~s}, 4 \mathrm{p}, 4 \mathrm{~d}$, and $5 \mathrm{~s}$ electrons for $\mathrm{Mo}$, and the $3 \mathrm{~s}$ and $3 \mathrm{p}$ electrons for $\mathrm{Cl}$. The mean value of the first-order electronic wave function, which is not an exact eigenstate of $S^{2}$ for unrestricted calculations on the triplet systems, was considered suitable for the unambiguous identification of the spin state. Spin contamination was carefully monitored, and the value of $\left\langle S^{2}\right\rangle$ for the UB3LYP (UB3LYP $=$ unrestricted B3LYP) calculations on the doublet $\mathrm{CpMo}\left(\eta^{4}-\mathrm{C}_{4} \mathrm{H}_{6}\right) \mathrm{XY}$ systems at convergence $\left(\mathrm{XY}=\mathrm{Cl}_{2}, 0.7655 ; \mathrm{ClMe}, 0.7644 ; \mathrm{Me}_{2}, 0.7636\right)$ indicated minor spin contamination.

Acknowledgement. We knowledge the Conseil Régional de Bourgogne, the MENRT, and the CNRS for financial support of this work, the European Commission for an Erasmus exchange undergraduate student program concerning J.D. from the University of Kaiserslautern, Germany, and the MENRT for a student followship to J.M.C. 
Supporting Information Available: A listing of positional coordinates, bond distances and angles, anisotropic displacement parameters, and calculated $\mathrm{H}$ atom positions for compounds $\mathbf{2}^{\prime \prime} \mathbf{a}, \mathbf{4}, \mathbf{4}^{\prime \prime}$, and 6. This material is available free of charge via the Internet at http://pubs.acs.org.

\section{References}

(1) Lappert, M. F.; Lednor, P. W. Adv. Organomet. Chem. 1976, 14, 345-399.

(2) Kochi, J. K. J. Organomet. Chem. 1986, 300, 139-166.

(3) Stiegman, A. E.; Tyler, D. R. Comments Inorg. Chem. 1986, 5, 215-245.

(4) Baird, M. C. Chem. Rev. 1988, 88, 1217-1227.

(5) Astruc, D. Chem. Rev. 1988, 88, 1189-1216.

(6) Organometallic Radical Processes; Trogler, W. C., Ed.; Elsevier: Amsterdam, 1990; Vol. 22.

(7) Siegert, F. W.; De Liefde Meijer, H. J. J. Organomet. Chem. 1970, 23, 177-183.

(8) Elson, I. H.; Kochi, J. K.; Klabunde, U.; Manzer, L. E.; Parshall, G. W.; Tebbe, F. N. J. Am. Chem. Soc. 1974, 96, 7374-7375.

(9) Manzer, L. Inorg. Chem. 1977, 16, 525-528.

(10) Cooper, N. J.; Green, M. L. H.; Mahtab, R. J. Chem. Soc., Dalton Trans. 1979, 1557-1562.

(11) Hayes, J. C.; Pearson, G. D. N.; Cooper, N. J. J. Am. Chem. Soc. 1981, 103, 4648-4650.

(12) Asaro, M. F.; Cooper, S. R.; Cooper, N. J. J. Am. Chem. Soc. 1986, 108, 5187-5193.

(13) Legzdins, P.; Shaw, M. J. J. Am. Chem. Soc. 1994, 116, 7700- 7705.

(14) Legzdins, P.; Shaw, M. J.; Batchelor, R. J.; Einstein, F. W. B. Organometallics 1995, 14, 4721-4723.

(15) Poli, R.; Krueger, S. T.; Abugideiri, F.; Haggerty, B. S.; Rheingold, A. L. Organometallics 1991, 10, 3041-3046.

(16) Morales, D.; Poli, R.; Richard, P.; Andrieu, J.; Collange, E. J. Chem. Soc., Dalton Trans. 1999, 867-874.

(17) Fryzuk, M. D.; Jafarpour, L.; Rettig, S. J. Organometallics 1999, 18, 4050-4058.

(18) Davidson, J. L.; Davidson, K.; Lindsell, W. E.; Murrall, N. W.; Welch, A. J. J. Chem. Soc., Dalton Trans. 1986, 1677-1688.

(19) Poli, R.; Wang, L.-S. Coord. Chem. Rev. 1998, 178-179, 169-189, and references therein.

(20) Le Grognec, E.; Poli, R.; Wang, L.-S. Inorg. Chem. Commun. 1999, 2, 95-96.

(21) Wang, L.-S.; Fettinger, J. C.; Poli, R. J. Am. Chem. Soc. 1997, 119, 4453-4464.

(22) Poli, R.; Wang, L.-S. Polyhedron 1998, 17, 3689-3700.

(23) Faller, J. W.; Murray, H. H.; White, D. L.; Chao, K. H. Organometallics 1983, 2, 400-409.

(24) Vong, W.-J.; Peng, S.-M.; Lin, W.-J.; Liu, R.-S. J. Am. Chem. Soc. 1991, 113, 573-582.

(25) Wang, L.-S.; Fettinger, J. C.; Poli, R.; Meunier-Prest, R. Organometallics 1998, 17, 26922701.

(26) Yasuda, H.; Nakamura, A. Angew. Chem., Int. Ed. Engl. 1987, 26, 723-742.

(27) Chisholm, M. H. Acc. Chem. Res. 1990, 23, 419-425.

(28) Huq, F.; Mowat, W.; Shortland, A.; Skapski, A. C.; Wilkinson, G. J. Chem. Soc., Chem. Commun. 1971, 1079-1080.

(29) Beshouri, S. M.; Rothwell, I. P. Polyhedron 1986, 5, 1191-1195.

(30) Chisholm, M. H.; Huffman, J. C.; J., T. R. J. Am. Chem. Soc. 1983, 105, 2075-2077. 
(31) Chisholm, M. H.; Folting, K.; Huffman, J. C.; Rothwell, I. P. Organometallics 1982, 1, 251-259.

(32) Coffindaffer, T. W.; Rothwell, I. P.; Huffmann, J. C. J. Chem. Soc., Chem. Commun. 1983, 1249-1251.

(33) Chisholm, M. H.; Folting, K.; Huffman, J. C.; Kramer, K. S.; Tatz, R. J. Organometallics 1992, 11, 4029-4036.

(34) Chisholm, M. H.; Haitko, D. A.; Folting, K.; Huffman, J. C. J. Am. Chem. Soc. 1981, 103, 4046-4053.

(35) Chetcuti, M. J.; Chisholm, M. H.; Folting, K.; Huffman, J. C.; Janos, J. J. Am. Chem. Soc. 1982, 104, 4684-4686.

(36) Chetcuti, M. J.; Chisholm, M. H.; Folting, K.; Haitko, D. A.; Huffman, J. C.; Janos, J. J. Am. Chem. Soc. 1983, 105, 1163-1170.

(37) Chetcuti, M. J.; Chisholm, M. H.; Chiu, H. T. Polyhedron 1985, 4, 1213-1217.

(38) Chetcuti, M. J.; Chisholm, M. H.; Folting, K.; Haitko, D. A.; Huffman, J. C. J. Am. Chem. Soc. 1982, 104, 2138-2146.

(39) Chisholm, M. H.; Clark, D. L.; Huffman, J. C.; Van Der Sluys, W. G.; Kober, E. M.;

Lichtenberger, D. L.; Bursten, B. E. J. Am. Chem. Soc. 1987, 109, 6796-6816.

(40) Chisholm, M. H.; Huffman, J. C.; J., T. R. J. Am. Chem. Soc. 1984, 106, 5385-5386.

(41) Aizenberg, M.; Turculet, L.; Davis, W. M.; Shattenmann, F.; Schrock, R. R. Organometallics 1998, 17, 4795-4812.

(42) Fagan, P. J.; Manriquez, J. M.; Maata, E. A.; Seyam, A. M.; Marks, T. J. J. Am. Chem. Soc. 1981, 103, 6650-6667.

(43) Debad, J. D.; Legzdins, P.; Rettig, S. J.; Veltheer, J. E. Organometallics 1993, 12, 27142725.

(44) Foo, T.; Bergman, R. G. Organometallics 1992, 11, 1801-1810.

(45) Poli, R. J. Coord. Chem. B 1993, 29, 121-173.

(46) Legzdins, P.; McNeil, W. S.; Shaw, M. J. Organometallics 1994, 13, 562-568.

(47) Lappert, M. F.; Pickett, C. J.; Riley, P. I.; Yarrow, P. I. W. J. Chem. Soc., Dalton Trans. 1981, 805-813.

(48) Chaloyard, A.; Dormond, A.; Tirouflet, J.; El Murr, N. J. Chem. Soc., Chem. Commun. 1980, 214-216.

(49) Mugnier, Y.; Moïse, C.; Laviron, E. J. Organomet. Chem. 1981, 204, 61-66.

(50) Herring, F. G.; Legzdins, P.; Richter-Addo, G. B. Organometallics 1989, 8, 1485-1493.

(51) Legzdins, P.; Veltheer, J. E. Acc. Chem. Res. 1993, 26, 41-48.

(52) Heaton, B. T. J. Chem. Soc., Chem. Commun. 1973, 931-932.

(53) Hunt, C. T.; Balch, A. L. Inorg. Chem. 1982, 21, 1641-1644.

(54) Linck, R. G.; Owens, B. E.; Poli, R.; Rheingold, A. L. Gazz. Chim. Ital. 1991, 121, 163168.

(55) Ryan, O. B.; Tilset, M.; Parker, V. D. J. Am. Chem. Soc. 1990, 112, 2618-2626.

(56) Tyler, D. R. Acc. Chem. Res. 1991, 24, 325-331.

(57) Tsou, T. T.; Kochi, J. K. J. Am. Chem. Soc. 1978, 100, 1634-1635.

(58) Lau, W.; Huffman, J. C.; Kochi, J. K. Organometallics 1982, 1, 155-169.

(59) Pedersen, A.; Tilset, M. Organometallics 1993, 12, 56-64.

(60) Pedersen, A.; Tilset, M. Organometallics 1994, 13, 4887-4894.

(61) Fooladi, E.; Tilset, M. Inorg. Chem. 1997, 36, 6021-6027. 
(62) Magnuson, R. H.; Zulu, S.; T'sai, W.-M.; Giering, W. P. J. Am. Chem. Soc. 1980, 102, 6887-6888.

(63) Magnuson, R. H.; Meirowitz, R.; Zulu, S.; Giering, W. P. J. Am. Chem. Soc. 1982, 104, 5790-5791.

(64) Magnuson, R. H.; Meierowitz, R.; Zulu, S. J.; Giering, W. P. Organometallics 1983, 2 , 460-462.

(65) Reger, D. L.; Mintz, E. Organometallics 1984, 3, 1759-1761.

(66) Bly, R. S.; Silverman, G. S.; Bly, R. K. Organometallics 1985, 4, 374-383.

(67) Reger, D. L.; Mintz, E.; Lebioda, L. J. Am. Chem. Soc. 1986, 108, 1940-1949.

(68) Golovin, M. N.; Meirowitz, R.; Rahman, M. M.; Liu, H. Y.; Prock, A.; Giering, W. P. Organometallics 1987, 6, 2285-2289.

(69) Therien, M. J.; Trogler, W. C. J. Am. Chem. Soc. 1987, 109, 5127-5133.

(70) Reger, D. L.; Klaeren, S. A.; Babin, J. E.; Adams, R. D. Organometallics 1988, 7, 181-189.

(71) Liu, H.-Y.; Golovin, N.; Fertal, D. A.; Tracey, A. A.; Eriks, K.; Giering, W. P.; Prock, A. Organometallics 1989, 8, 1454-1458.

(72) Butler, I. S.; Basolo, F.; Pearson, R. G. Inorg. Chem. 1967, 6, 2074-2079.

(73) Wax, M. J.; Bergman, R. G. J. Am. Chem. Soc. 1981, 103, 7028-7030.

(74) Teuben, J. H.; de Boer, E. J. M.; Klazinga, A. H.; Klei, E. J. Mol. Catal. 1981, 13, 107114.

(75) de Boer, E. J. M.; de With, J. J. Organomet. Chem. 1987, 320, 289-293.

(76) Luinstra, G. A.; Ten Cate, L. C.; Heeres, H. J.; Pattiasina, J. W.; Meetsma, A.; Teuben, J. H. Organometallics 1991, 10, 3227-3237.

(77) Duling, D. R. P.E.S.T., v. 0.96; National Institute of Environmental Health Sciences: Research Triangle Park, NC, 1996.

(78) Vogel, A. Vogel's Textbook of Practical Organic Chemistry, $4^{\text {th }}$ ed.; Longman: London, $1978 ; \mathrm{p} 638$.

(79) North, A. C. T.; Phillips, D. C.; Mathews, F. S. Acta Crystallogr., Sect. A 1968, A24, 351359.

(80) Spek, A. L. Acta Crystallogr., Sect. A: Found. Crystallogr. 1990, 46, C34.

(83) Frisch, M. J.; Trucks, G. W.; Schlegel, H. B.; Gill, P. M. W.; Johnson, B. G.; Robb, M. A.; Cheeseman, J. R.; Keith, T. A.; Petersson, G. A.; Montgomery, J. A.; Raghavachari, K.; Al-Laham, M. A.; Zakrzewski, V. G.; Ortiz, J. V.; Foresman, J. B.; Cioslowski, J.; Stefanov, B. B.; Nanayakkara, A.; Challacombe, M.; Peng, C. Y.; Ayala, P. Y.; Chen, W.; Wong, M. W.; Andres, J. L.; Replogle, E. S.; Gomperts, R.; Martin, R. L.; Fox, D. J.; Binkley, J. S.; Defrees, D. J.; Baker, J.; Stewart, J. P.; Head-Gordon, M.; Gonzales, C.; Pople, J. A. Gaussian 94 (Revision E.1); Gaussian Inc.: Pittsburgh, PA, 1995.

(84) Becke, A. D. J. Chem. Phys. 1993, 98, 5648-5652.

(85) Dunning, T. H., Jr.; Hay, P. J. In Modern Theoretical Chemistry; Schaefer, H. F., III, Ed.; Plenum Press: New York, 1976; pp 1-28.

(86) Hay, P. J.; Wadt, W. R. J. Chem. Phys. 1985, 82, 270-283.

(87) Wadt, W. R.; Hay, P. J. J. Chem. Phys. 1985, 82, 284-298.

(88) Hay, P. J.; Wadt, W. R. J. Chem. Phys. 1985, 82, 299-310.

(89) Johnson, C. K. ORTEP, Report ORNL-5138; Oak Ridge National Laboratory: Oak Ridge, TN, 1976. 